\title{
Early-Life Origins of Type 2 Diabetes: Fetal Programming of the Beta-Cell Mass
}

\author{
Bernard Portha, Audrey Chavey, and Jamileh Movassat \\ Université Paris-Diderot, Sorbonne-Paris-Cité, Laboratoire B2PE (Biologie et Pathologie du Pancréas Endocrine), \\ Unité BFA (Biologie Fonctionnelle et Adaptive), EAC 4413 Centre National de la Recherche Scientifique, 75205 Paris, France \\ Correspondence should be addressed to Bernard Portha, portha@univ-paris-diderot.fr
}

Received 30 May 2011; Revised 2 August 2011; Accepted 2 August 2011

Academic Editor: Christine Maric-Bilkan

Copyright ( $(2011$ Bernard Portha et al. This is an open access article distributed under the Creative Commons Attribution License, which permits unrestricted use, distribution, and reproduction in any medium, provided the original work is properly cited.

\begin{abstract}
A substantial body of evidence suggests that an abnormal intrauterine milieu elicited by maternal metabolic disturbances as diverse as undernutrition, placental insufficiency, diabetes or obesity, may program susceptibility in the fetus to later develop chronic degenerative diseases, such as obesity, hypertension, cardiovascular diseases and diabetes. This paper examines the developmental programming of glucose intolerance/diabetes by disturbed intrauterine metabolic condition experimentally obtained in various rodent models of maternal protein restriction, caloric restriction, overnutrition or diabetes, with a focus on the alteration of the developing beta-cell mass. In most of the cases, whatever the type of initial maternal metabolic stress, the beta-cell adaptive growth which normally occurs during gestation, does not take place in the pregnant offspring and this results in the development of gestational diabetes. Therefore gestational diabetes turns to be the ultimate insult targeting the offspring beta-cell mass and propagates diabetes risk to the next generation again. The aetiology and the transmission of spontaneous diabetes as encountered in the GK/Par rat model of type 2 diabetes, are discussed in such a perspective. This review also discusses the non-genomic mechanisms involved in the installation of the programmed effect as well as in its intergenerational transmission.
\end{abstract}

\section{Perinatal Risk Factors for Diabetes in Later Life}

Type 2 diabetes mellitus (T2D) is a complex polygenic disease that often manifests years before eventual clinical diagnosis [1]. T2D develops as a result of a failure to adequately increase beta-cell function and mass to meet the demands of prevailing insulin resistance [2]. The contribution of beta-cell failure to the pathophysiology of T2D is supported by islet pathology that reveals a betacell deficit of approximately 50 and $65 \%$ in individuals with impaired fasting glucose and T2D, respectively [3]. Consistent with these observations, most genes linked to T2D by genome-wide association scans have been shown to influence some aspects of beta-cell biology, such as regulation of beta-cell secretory function and development and growth of beta-cell mass [4]. It has long been recognized that nutrient availability during fetal and early postnatal life is an important determinant of adult health [5].
There are strong arguments showing that $\mathrm{T} 2 \mathrm{D}$ is more prevalent among subjects that were in utero exposed to maternal diabetes (IUED). The role of maternal inheritance in T2D has been reported in a majority of epidemiological studies $[6,7]$. To determine the role of the intrauterine diabetic environment per se, the prevalence of diabetes was compared in Pima nuclear families in which at least one sibling was born before and one after the mother was diagnosed with T2D. Offspring born after their mother displayed diabetes had a fourfold higher risk of diabetes and a higher body mass index (BMI) than their full siblings born before their mother developed diabetes [8]. These findings indicate that intrauterine exposure to a diabetic environment increases risk of obesity and T2D beyond that attributable to genetic factors, at least in Pima Indians. To circumvent the confounding effect of genes linked to early onset T2D and transmitted by the pregnant T2D mother, the effect of fetal exposure to T1D was evaluated in adult offspring lacking T1D immunological markers. A 33\% prevalence of 
IGT was reported in offspring of T1D mothers compared with none in offspring of T1D fathers (control group) [9]. Altogether, these findings suggest that fetal exposure to maternal diabetes is indeed associated with abnormal glucose homeostasis in offspring and may participate in the excess of maternal transmission in T2D. In adult Pima Indians with normal glucose tolerance and who had been exposed to an intrauterine diabetic environment, acute insulin response to i.v. glucose was found reduced in those offspring whose mother was diabetic before pregnancy while it remained normal in those whose mother developed diabetes after pregnancy, [10]. Body fat and insulin sensitivity (euglycemic hyperinsulinemic clamp) were similar in the two groups of subjects [10]. In the same study, acute insulin response was found reduced in offspring of parents (mother or father) with early onset of T2D [10], suggesting that gene(s) linked to early-onset diabetes is(are) associated with reduced insulin secretory response to glucose [11]. Offspring of T1D mothers had reduced insulin secretion, more pronounced in IGT subjects, but similar fat mass and insulin action compared with offspring of T1D fathers [9]. Also in nondiabetic offspring of mothers with young-onset T2D (diagnosed under age 50), beta-cell function (early insulin release after oral glucose) was found decreased as compared to that of offspring of fathers with young-onset T2D [12]. Therefore, human studies suggest that insulin secretion defect participates in the abnormal glucose tolerance observed in adult offspring exposed to maternal diabetes during fetal life. Importantly, they showed that insulin secretion may be reduced even in normal glucose-tolerant offspring. Nevertheless, in children and adolescent offspring, insulin resistance involvement was suggested and may be related, at least in part, to their higher body weight.

Beside studies in IUED populations, prenatal nutrient insufficiency resulting in low birth weight is also associated with increased risk for development of obesity, cardiovascular disease, and T2D [13-15]. The association between low birth weight and development of T2D was first reported in classic studies by Hales et al. [15] that demonstrated a severalfold increase in the incidence of glucose intolerance and T2D in adult males that were born small compared with those who were born at a normal birth weight. These seminal observations since have been consistently reproduced by numerous investigators worldwide [16]. Although epidemiological evidence linking low birth weight with increased susceptibility to T2DM is strong [16], the molecular and physiological mechanisms underlying this association are still under investigation [17]. It has long been appreciated that low birth weight is associated with adult insulin resistance, which can contribute to the increased risk in development of T2D [18]. However, susceptibility to T2D in low-birth-weight individuals has also been hypothesized to be attributed to inadequate beta-cell mass formation [15]. Because it is not possible to measure beta-cell mass in vivo, this hypothesis cannot yet be tested directly in humans. However, evidence suggests that inadequate beta-cell formation in utero may underlie subsequent susceptibility for T2D. First, the fetal period is critical for endocrine pancreatic development in rodents and humans [19]. Second, clinical data show that children and adults with low birth weight demonstrate impaired beta-cell function compared with their normal birth-weight counterparts $[20,21]$ and human fetuses with severe growth retardation, have a reduction in pancreatic endocrine cell mass [22].

In this paper, we discuss the evidence for beta-cell dysfunction in IUED (in utero exposed to maternal diabetes), IUEO (in utero exposed to maternal overnutrition) and IUGR (in utero growth restriction) animal models, focusing on the strengths and limits of each, in order to define critical periods and types of alterations that can lead to impaired beta-cell function. We also discuss several potential mechanisms dissected in relevant animal models that begin to explain this outcome.

\section{Compromised Intrauterine Environment and Risk for Diabetes in Later Life}

Thanks to abundant studies mostly in rodents in which the foetal environment can be manipulated, a substantial body of data now addresses the mechanisms involved in the developmental programming of glucose intolerance and T2D.

IUED Models. In rat, maternal diabetes may be induced experimentally by streptozotocin (STZ) injection that selectively destroys beta-cells. Mild or severe diabetes ensue depending on the dose used. At birth, the progeny of mild diabetic mothers had normal weight or slight macrosomia and an enhanced percentage of pancreatic endocrine tissue due to hyperplasia and hypertrophy of the islet cells [24, 25], leading to a higher beta-cell mass that was hypervascularized [26]. The pancreatic insulin content and insulin secretion were raised in these fetuses [27]. On the other hand, fetuses from severe diabetic dams were small at birth and had decreased pancreatic weight [28]. Their beta-cells were almost degranulated, leading to low pancreatic insulin content and low plasma insulin [27]. Similar endocrine pancreas/beta-cell alterations with low beta-cell mass have been reported in fetuses from spontaneous diabetic BB rats [29] or spontaneous diabetic GK rats [30, 31]. The longterm consequences have been evaluated in the progeny of these models. Impaired glucose tolerance was observed in the offspring of mild STZ diabetic rats due to lower insulin secretion in response to glucose, while insulin resistance was reported in the offspring of the severe STZ diabetic mothers [32-34]. Glucose tolerance was also impaired in offspring of normal mothers receiving glucose infusion during late gestation, and it was associated with decreased glucoseinduced insulin secretion [24, 35-37].

The greatest difficulty in most animal models of diabetic pregnancy has been the attainment of a stable degree of mild hyperglycemia during gestation. Though useful, most techniques used to achieve models of diabetes in pregnancy have some drawbacks. Maternal glucose infusions limited to the last trimester of pregnancy result in hyperglycemia and hyperinsulinemia and do not mimic the relative insulin deficiency of gestational diabetes [38]. The multiple lipid 
and protein abnormalities associated with diabetes may be as important in the induction of fetal abnormalities as hyperglycemia, but they are not replicated by the maternal glucose infusion model. A concern of studies using STZ during pregnancy is the possibility that the toxin might cross the placenta and be directly harmful to the fetal pancreas and other fetal tissues, and thus make any analysis of the long-term effects of hyperglycemia in utero difficult [39]. The problem may be circumvented by giving STZ to female neonates who will later become pregnant: this will result in moderate gestational hyperglycemia [40]. Finally it must be recognized that none of the previously mentioned models will serve directly as a model of human gestational diabetes.

An ideal animal model to test the isolated impact of diabetic pregnancy would enter the pregnancy in a euglycemic state, become exposed to hyperglycaemic during whole pregnancy, and return postpartum to normoglycemic environment. Such a model also would allow study of the long-term effects of diabetes independent of any genetic influence. It was recently proposed that the pregnant GK rat being transferred normal Wistar (W) rat embryo represents a more relevant paradigm in such a perspective [41]. Using the GK/Par rat (Figure 1) we have transferred $W$ rat oocytes to diabetic GK/Par females, and at their birth the $\mathrm{W}$ neonates were suckled by nondiabetic $\mathrm{W}$ foster mothers. Under these unique conditions, we have found that maternal diabetes negatively imprints the growth of a genetically normal (Wistar) beta-cell mass in a way as the insult is still present later at adult age as a decreased beta-cell population $[42,43]$. Not only maternal diabetes but also intrauterine undernutrition induced by several means such as protein (IUPR) or calorie (IUCR) restriction, or alteration in the availability of the nutrients by uterine/placental insufficiency (UPI) induced by uterine artery ligation, alter early islet development and provoke lasting consequences in rodents.

IUCR Models. Global restrictions (to $40-50 \%$ of normal intake) (IUCR) in the last week of rat pregnancy results in low birth weight offspring with decreased beta-cell mass. Although these animals can regain their body and pancreatic weights upon normal postnatal feeding, they still demonstrate a reduced beta-cell mass and insulin content in adulthood [44, 45]. Extending this level of nutrient restriction during suckling results in a permanent reduction of beta-cell mass $[46,47]$ and subsequent age-dependent loss of glucose tolerance in the offspring [48]. Underfeeding the rat mothers during the first two weeks of gestation exerts no adverse effect upon insulin secretion and insulin action in the adult male offspring [49].

IUPR Models. The maternal protein restriction $(5-8 \%$ as compared to $20 \%$ in normal diet) (IUPR) model has been one of the most extensively studied models. The low-proteinfed mothers give birth to growth-restricted offspring [5054], and when suckled by their mothers maintained on the same low-protein fed, they remain permanently growth restricted, despite being weaned on a normal diet [53]. Reduced placental weight and endocrine and metabolic abnormalities are also observed $[50,55,56]$. Despite young offspring of low-protein-fed dams demonstrating improved glucose tolerance $[56,57]$, the male offspring undergo an age-dependent loss in glucose tolerance, such that by 17 months of age they develop $\mathrm{T} 2 \mathrm{D}$ and insulin resistance [58]. Female offspring only develop hyperinsulinemia and impaired glucose tolerance at a much later age (21 months) [54]. Studies in this model have also demonstrated reductions in beta-cell mass [51], skeletal muscle mass [53], central adipose deposit weights $[57,59]$, and insulin signalling defects in muscle, adipocytes, and liver [59-61]. This IUPR model has also been associated with the development of hypertension with the kidney and the rennin-angiotensin system as playing a role [62].

UPI Models. Fetal growth retardation may also result from experimental uteroplacental insufficiency (UPI). Fetal UPI rats have decreased levels of glucose, insulin, IGF1, amino acids, and oxygen [63-65]. UPI offspring develop diabetes in later life $[66,67]$ with a phenotype that is similar to that observed in T2D humans with alterations in insulin secretion and action and a failure of beta-cell function and growth $[68,69]$.

IUEO Models. There are several reports on the consequences of a high-fat diet (during gestation only or both gestation and lactation) on the adult progeny. High-fat diet consumption by female rats malprograms the male offspring for glucose intolerance and increased body weight in adulthood [70]. Some of the observed consequences include reduced wholebody insulin sensitivity, impaired or normal insulin secretion and changes in the structure of pancreas [71-74], defective mesenteric artery endothelial function [75], hypertension $[76,77]$, alterations in renal functions [78], increased body adiposity $[72,76]$, deranged blood lipid profile $[71,76$, 78], hyperleptinemia [72], and proatherogenic lesions [79]. There are not many reports on fetal islet adaptations due to a high-fat dietary modification in the dam. Cerf et al. [80] demonstrated that feeding rat female with a high-fat diet throughout gestation resulted in significant decreases in beta-cell volume and number resulting in hyperglycemia in 1-day-old newborn rat pups without changes in serum insulin concentrations. However, the report of fetal hyperinsulinemia in the high-fat term rat fetus [70] is not consistent with this finding.

Maternal obesity in mice, in the absence of diabetes, can also impair glucose tolerance in genetically normal offspring. This was shown using mothers carrying the Agouti (Ay) mutation on a C57BL/6 background. On this background, the Ay mutation produces marked obesity without diabetes. At adult age while maintained on normal diet, genetically normal, adult female offspring of Ay-positive mothers exhibited reduced glucose-induced insulin secretion in vivo [81].

Also male mice whose mothers consumed a high-fat diet were heavier, glucose intolerant, and insulin resistant and produced second-generation offspring who were insulin resistant, although not obese [82]. Whether this is 


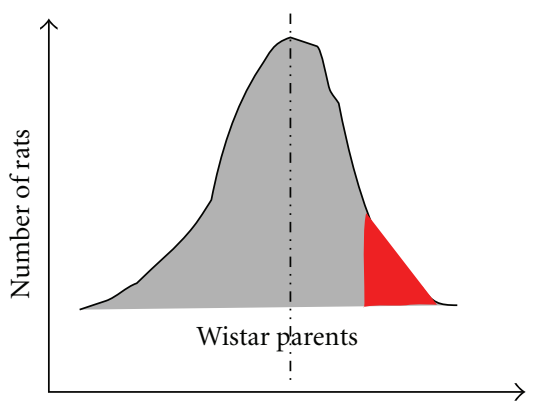

$\sum$ blood glucose (OGTT)

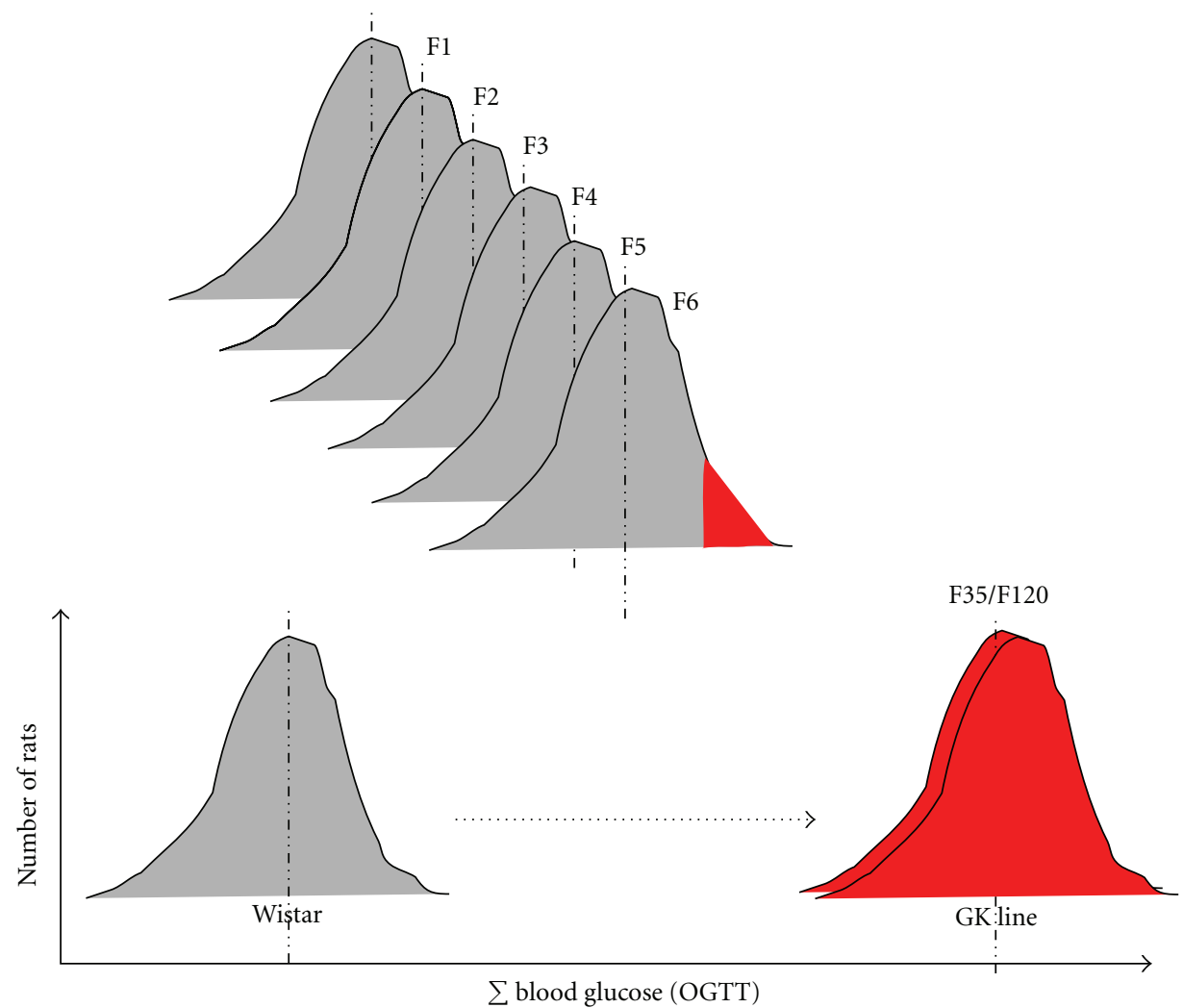

FIGURE 1: From the nondiabetic Wistar rat to the spontaneously diabetic GK (Goto-Kakizaki) rat. The inbred GK rat line (Wistar strain) was produced by Goto et al. at Tohoku University, Sendaï, Japan, by selective breeding of normal Wistar rats over many generations using glucose tolerance value (and not basal glucose value only) as a discriminant phenotype [23]. Only W rats selected at the upper limit of normal distribution for glucose tolerance were used. The diabetic state (basal hyperglycemia) was reported to become stable after the 30 generations of selective crosses in the original Japanese colony. Here is illustrated the distribution of the sum of blood glucose values ( $\sum$ blood glucose) during standardised oral glucose tolerance tests (OGTTs) performed in original parent Wistar rats, in rats from generations F1 to F35 in the original Japanese colony and in rats from generations F35 to F120 bred under our conditions in Paris from 1989 until now (subline GK/Par). In the inbred GK/Par rat line, all rats are nonoverweight, nonketotic, and display moderate fasting hyperglycemia with strong postprandial glucose intolerance. No attenuation, nor aggravation, of the diabetic phenotype overtime (more than 20 years and 80 generations) was registered in the GK/Par line.

a consequence of paternal in utero exposure or their adult sequelae of obesity and diabetes is unclear. It was recently reported that chronic high-fat diet consumption in father rats induced increased body weight, adiposity, impaired glucose tolerance, and insulin sensitivity in their offspring
[83]. Relative to controls, their female offspring had an early onset of impaired insulin secretion and glucose tolerance that worsened with time and normal adiposity. Among the differentially expressed islet genes, hypomethylation of the Il13ra2 gene was demonstrated. This is a proof of 


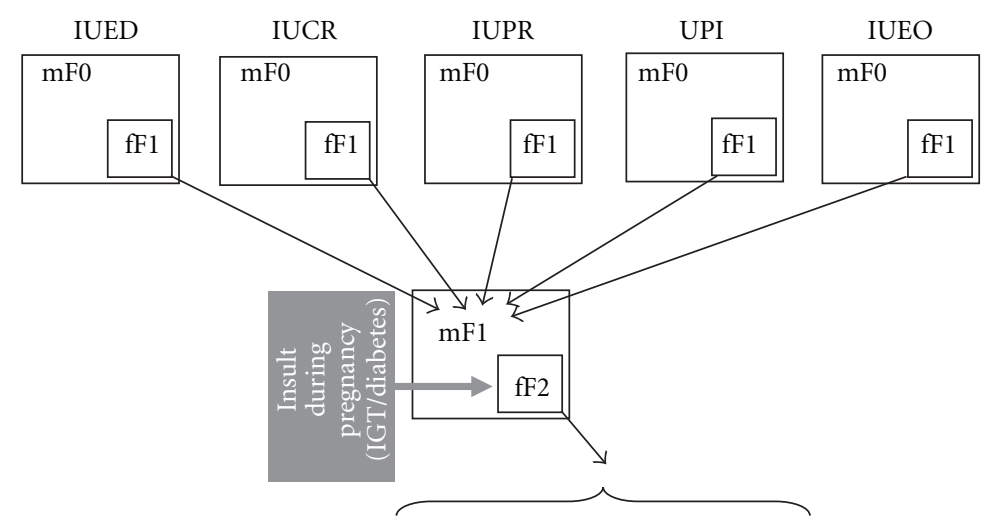

(1)

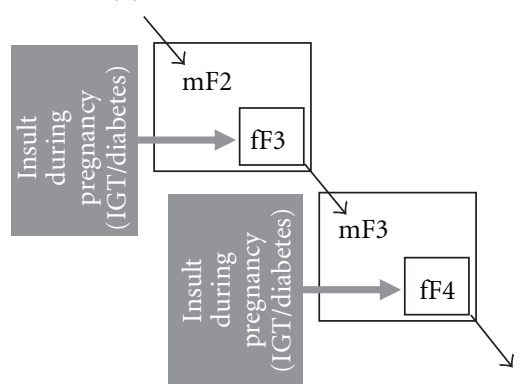

(2)

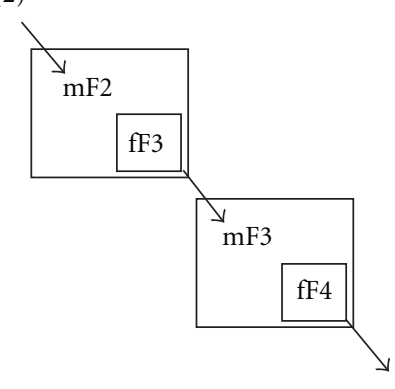

FIGURE 2: Mechanisms for the installation and intergenerational transmission of programmed beta cell mass (BCM) disruption in response to compromised intrauterine environment. The initial insults in F0 mother ( $\mathrm{mF} 0$ ) impact the developing BCM of the fetuses (fF1). Diverse initial insults (IUED, IUCR, IUPR, UPI, IUEO), alone or in combination, give rise to the same programmed BCM outcome. Altered BCM phenotype in F1 females does not allow normal BCM adaptation during pregnancy and IGT/diabetes ensues (gestational diabetes). Gestational diabetes in the F1 pregnant mother ( $\mathrm{mF} 1$ ) acting as an ultimate insult impacts the developing BCM of the F2 fetuses (fF2). Altered BCM phenotype in F2 females does not allow normal BCM adaptation during pregnancy and IGT/diabetes ensues (gestational diabetes). Gestational diabetes in the F2 pregnant mother ( $\mathrm{mF} 2$ ) acting as an ultimate insult impacts the developing BCM of the F3 fetuses (fF3), therefore perpetuating similar BCM programming across generations. There are at least two potential scenarii for the transmission of BCM programming to subsequent generations: (1) the insult as seen in the F1 mother (IGT/diabetes insult during pregnancy) directly impairs BCM development, but BCM malprogramming is not necessarily irreversible. However, as the environmental insult (gestational diabetes) persists across generations, it recreates the same gestational phenotype in each subsequent generation (panel 1 in Figure 2); (2) the insult as seen in the F1 mother permanently affects BCM and results in the perpetuation of BCM malprogramming in the subsequent generations, in the absence of a further gestational insult (panel 2 in Figure 2). M: mother; f: fetus; F1: first-generation animals procreated by parent (F0) females submitted to experimentally disturbed metabolism during their pregnancy; F2: second-generation animals procreated by F1 females exposed to intrauterine-disturbed metabolism; IUED: in utero exposed to maternal diabetes; IUCR: in utero exposed to maternal calorie restriction; IUPR: in utero exposed to maternal protein restriction; UPI: uteroplacental insufficiency; IUEO: in utero exposed to maternal overnutrition or obesity.

concept that paternal high-fat-diet exposure programs betacell dysfunction in rat F1 female offspring. This is the first report in mammals of nongenetic, intergenerational transmission of metabolic sequelae of a high-fat diet from father to offspring [83].

Among the many types of maternal metabolic stress used to produce IUGR, hypercholesterolemia combined to high fat diet was recently added since feeding LDL receptor null $\left(\mathrm{LDLR}^{-/-}\right)$mice with a high-fat resulted in litters with significant growth retardation. The $\mathrm{LDLR}^{-/-}$high-fat diet offspring developed significantly larger atherosclerotic lesions by 90 days compared with chow diet offspring [84]. Importantly, maternal hypoaminoacidemia proved to be an important antecedent in this hypercholesterolemic IUGR mouse [84] as in a protein-deficient IUGR mouse model [84] and an IUED rat model [85]. It may be an important link in the mechanisms that contribute to adult-onset glucose intolerance, obesity, and atherosclerosis. In this study betacell mass was not investigated.

To sum up, it turns to be manifest that, despite differences in the type, timing, and duration of intrauterine insult, most animal models of IUED, IUCR, IUPR, or IUEO have outcomes of impaired glucose tolerance or T2D (Figure 2).

\section{Various Early-Life Stressors, the Same Target: The Developing Beta-Cell Mass}

As abundantly illustrated in animal models, many early-life stressors such as maternal hyperglycaemia, undernutrition, overnutrition, hypercholesterolemia, corticosteroid therapy, uteroplacental insufficiency, or hypoxia trigger a beta-cell mass adaptive response in the fetus (Figure 2, Table 1). 
TABLE 1: Beta-cell (BC) mass characteristics in rodent models of compromised intrauterine environment.

\begin{tabular}{|c|c|c|c|}
\hline \multirow{2}{*}{ Rodent models } & \multicolumn{3}{|c|}{ BC phenotype } \\
\hline & fetal & neonatal/suckling & adult \\
\hline IUED, mild STZD (F1) & $\begin{array}{l}\text { Increased BC mass, high BC } \\
\text { proliferation [24-27] }\end{array}$ & $\begin{array}{l}\text { Increased BC mass, high } \\
\mathrm{BC} \text { proliferation, high islet } \\
\text { vascularisation }[24,25]\end{array}$ & $\begin{array}{l}\text { Normal BC mass, low } \\
\text { GSIS, low GT [24] }\end{array}$ \\
\hline F2 issued from mild STZD F1 & NR & NR & $\begin{array}{l}\text { Low GSIS, low GT } \\
{[26,32]}\end{array}$ \\
\hline IUED, severe STZD (F1) & low $\mathrm{BC}$ mass $[27,28]$ & NR & $\begin{array}{l}\text { Increased BC mass, } \\
\text { high GSIS, low GT } \\
{[32-34,39]}\end{array}$ \\
\hline IUED, GI (F1) & $\begin{array}{l}\text { Slightly increased BC mass, } \\
\text { high BC proliferation [35] }\end{array}$ & NR & $\begin{array}{l}\text { Low GSIS, low GT } \\
{[24,35-38]}\end{array}$ \\
\hline F2 issued from GI F1 & NR & NR & $\begin{array}{l}\text { Low GSIS, low GT } \\
{[35]}\end{array}$ \\
\hline IUED, GK/Par & $\begin{array}{l}\text { Low BC mass, low BC } \\
\text { neogenesis }[30,31,42,86,87]\end{array}$ & $\begin{array}{l}\text { Low BC mass, low BC } \\
\text { neogenesis }[88]\end{array}$ & $\begin{array}{l}\text { Low BC mass, low BC } \\
\text { proliferation, low } \\
\text { GSIS }[23,88,89]\end{array}$ \\
\hline Severe IUCR (F1) & $\begin{array}{l}\text { Increased } B C \text { mass, high } B C \\
\text { neogenesis, high } B C \\
\text { proliferation }[46,90-92]\end{array}$ & NR & $\begin{array}{l}\text { Low BC mass, low BC } \\
\text { proliferation, low } \\
\text { GSIS [46] }\end{array}$ \\
\hline IUCR (F1) & $\begin{array}{l}\text { Low BC mass, low BC } \\
\text { neogenesis }[44,45,93]\end{array}$ & Low BC mass [47] & $\begin{array}{l}\text { Low BC mass, low } \\
\text { GSIS, low GT [44-49] }\end{array}$ \\
\hline F2 issued from IUCR F1 & $\begin{array}{l}\text { Low BC mass, low BC } \\
\text { neogenesis }[94]\end{array}$ & NR & $\begin{array}{l}\text { Low GSIS, low GT } \\
{[32]}\end{array}$ \\
\hline IUPR (F1) & $\begin{array}{l}\text { Low BC mass, low BC } \\
\text { proliferation, low islet } \\
\text { vascularization }[50,51,93,95]\end{array}$ & Low BC mass [93] & $\begin{array}{l}\text { Low BC mass, low } \\
\text { GSIS, low GT } \\
{[51,53,54,56-} \\
62,96-98]\end{array}$ \\
\hline $\mathrm{F} 2$ issued from IUPR F1 & Low BC mass [26] & NR & Normal GT [99] \\
\hline UPI (F1) & $\begin{array}{l}\text { Normal BC mass, low BC } \\
\text { proliferation, low islet } \\
\text { vascularization [63-65] }\end{array}$ & Normal BC mass [65-67] & $\begin{array}{l}\text { Low BC mass, low } \\
\text { GSIS, low GT } \\
{[66,67,100,101]}\end{array}$ \\
\hline $\mathrm{F} 2$ issued from UPI F1 & NR & NR & $\begin{array}{l}\text { Low BC mass, low BC } \\
\text { proliferation, low } \\
\text { GSIS, low GT [32] }\end{array}$ \\
\hline IUEO (F1) & NR & $\begin{array}{l}\text { Slightly reduced BC mass } \\
{[80]}\end{array}$ & $\begin{array}{l}\text { Normal or decreased } \\
\text { GSIS, low GT } \\
{[70-76,81-84]}\end{array}$ \\
\hline F2 issued from IUEO F1 & NR & NR & Normal GT [82] \\
\hline
\end{tabular}

NR: not reported in the literature to the author's knowledge; GSIS: glucose-stimulated insulin secretion; GT: glucose tolerance; STZD: diabetes obtained after streptozotocin administration to adult females several days before mating or during pregnancy; GI: continuous glucose infusion in unrestrained normal pregnant rat during the last week of pregnancy; F1: first-generation animals procreated by parent (F0) females submitted to experimentally disturbed metabolism during their pregnancy; F2: second-generation animals procreated by F1 females exposed to intrauterine disturbed metabolism; IUED: in utero exposed to maternal diabetes; IUCR: in utero exposed to maternal calorie restriction; IUPR: in utero exposed to maternal protein restriction; UPI: uteroplacental insufficiency; IUEO: in utero exposed to maternal overnutrition or obesity.

3.1. Critical Windows for Adaptive Response to Early-Life Stressors. The development of the endocrine pancreas starts from a pool of common precursor cells that become progressively committed to the endocrine lineage under the control of a hierarchical network of transcription factors. During late fetal and early postnatal life, the beta-cell mass is determined by the recruitment of undifferentiated precursors, as well as the replication and apoptosis rates of the beta cells. Obviously, any disturbance of the environment of the endocrine cells at a specific developmental time-point, as it occurs in a perturbed intrauterine milieu, may modify the balance of controlling factors, thereby contributing to an adaptive beta-cell growth response which is metabolically appropriate on the short term. However, this adaptive response may turn to be detrimental if maintained on the long term, as it may foster beta-cell failure and diabetes later in life. We are largely ignorant of when programming may be initiated during development.

Preimplantatio. An early onset for programming was indicated, as maternal low-protein diet during only the preimplantation period of rat development (0-4 days after 
mating), before return to control diet for the remainder of the gestation, induced blastocyst abnormalities, and programming of postnatal growth rate and hypertension [102]. More specifically it was shown that preimplantation embryos collected from dams after 0-4 days of maternal low-protein diet displayed significantly reduced cell numbers, within the inner cell mass and trophectoderm lineages, apparently induced by a slower rate of cellular proliferation. The lowprotein diet significantly reduced insulin and essential amino acid levels and increased glucose levels within maternal serum by day 4 of development. These data indicate that the mildly hyperglycemic and amino-acid-depleted maternal environment generated by undernutrition may act as an early mechanism of programming and initiate conditions of "metabolic stress," restricting early embryonic proliferation and the generation of appropriately sized stem-cell lineages. In chemically or genetically obtained rat diabetes models in which maternal serum insulin depletion and hyperglycemia are induced, proliferation of inner cell mass or total cell numbers within blastocysts is inhibited [103, 104]. Therefore, the preimplantation embryo is particularly sensitive to metabolic modifications that may have programming consequences $[105,106]$, and one possibility is that it is the preimplantation embryo itself that is programmed.

Postimplantation. Embryo transfer experiments may also help to dissociate the impact of the maternal environment in early (preimplantation) versus late gestation (postimplantation). We recently found that embryos (blastocysts) from a nondiabetic Wistar strain placed into a diabetic GK/Par uterus develop a reduced beta-cell mass which remains low on the long term [42]. Data with rat models of prenatal undernutrition [95] also illustrate that low-energy and lowprotein diets that reduce the development of the beta-cell mass in both cases act at different critical time windows. The beta-cell mass is deficient in the low-energy pancreas because this diet reduces neogenesis, probably because of high glucocorticoid levels, rather than by impairing vascularisation and proliferation. Early gestation is thus a very sensitive period in this model. By contrast, pancreatic alterations take place at a later fetal stage in the low-protein model, and the beta-cell mass is deficient in this case because this diet reduces betacell vascularisation and proliferation without altering betacell differentiation [95].

Postnatal versus Prenata. Further support for the crucial impact of prenatal nutritional environment is the recent report that prenatal nutrient restriction in both male and female rats led to an inappropriate postnatal beta-cell mass formation attributed to a decrease in the rate of beta-cell replication and beta-cell neogenesis [93]. In contrast, male and female rats exposed to postnatal nutrient restriction alone (with normal prenatal nutrient exposure) were characterized by decreased pancreatic and body weights, but a weight-adjusted beta-cell mass higher compared to control animals [93]. Another illustration is offered by observations in normal rat pups reared artificially on a high-carbohydrate milk formula [107]: such alteration of nutrition, during the suckling period only, induced persistent adaptation of energy metabolism in adulthood (obesity, glucose intolerance, and impaired insulin secretion).

\subsection{Molecular Mechanisms Mediating the Perinatal Beta-Cell} Adaptive Response to Early-Life Stressors. Molecular mechanisms responsible for impaired beta-cell mass formation after IUCR or IUPR have come under investigation.

First, it has been proposed that IUCR can result in a reduction of the embryonic beta-cell progenitor pool leading to inappropriate postnatal beta-cell formation. Stanger et al. [108] demonstrated that selective genetic reduction in the size of PDX-1+ pancreatic progenitors during the fetal period results in impaired beta-cell formation during the postnatal period with consequent development of glucose intolerance during adulthood. Consistent with this, maternal food restriction leads to significant reduction in PDX-1+ and neurogenin-3+ pancreatic precursors during embryonic development in rats, diminished postnatal beta-cell formation, and inability to expand beta-cell mass in response to pregnancy $[47,94]$. The UPI model is also characterized by a permanent decrease in islet PDX-1 mRNA expression. This decrease has recently been shown to be due to progressive epigenetic silencing of the $\mathrm{Pdx} 1$ gene locus secondary to proximal promoter methylation $[69,109]$, and it may be responsible for the decreased rate of beta-cell replication and inappropriate postnatal beta-cell mass development [69, 110]. In the same way of thinking, studies have demonstrated that the maintenance of methylated histone H3 Lys4 by Set7/9, a member of the SET methyltransferase family, is crucial to Pdx1 activity in beta-cell lines [111-113]. This led to the hypothesis that Set7/9 may represent a novel chromatin-modifying protein that functions in part through its recruitment to target genes by cell-specific transcription factors such as Pdx1. Since then, a role of histone methyl transferases, particularly set7, has also been demonstrated in the sustained deleterious effects of chronic hyperglycemia on human microvascular endothelial cells [114]. Such an epigenetic change could potentially be involved in the deleterious effect of high glucose upon the fetal pancreas in the IUED models.

Another mechanism proposed to explain reduced betacell formation after IUCR is related to prenatal glucocorticoid exposure. Administration of either dexamethasone or carbenoxolone (to inhibit $11 \beta$-hydroxysteroid dehydrogenase type 2) to normal pregnant rats also causes fetal growth retardation and the adult offspring are hypertensive and hyperglycemic, with hyperactive hypothalamicpituitary-adrenal axis [115]. Maternal undernutrition significantly increased both fetal and maternal corticosterone concentrations in rats [116]. Subsequently, maternal and/or fetal overexposure to glucocorticoids (via administration of dexamethasone) impairs both fetal and postnatal beta-cell formation in rodents and nonhuman primates [94, 117119]. Seckl et al. [115] have shown that fetal corticosterone concentrations are inversely correlated with fetal insulin content and postnatal beta-cell formation in rats. Evidence suggests that glucocorticoids can exert a direct effect on 
the developing fetal pancreas via transcriptional modulation of transcription factors involved in beta-cell formation and differentiation [117]. Glucocorticoid receptors are present in the pancreas during embryonic development of rodents and humans [117], and glucocorticoids can bind to the Pdx1 promoter and thus suppress fetal endocrine cell differentiation [117]. Glucocorticoid treatment has been shown to significantly reduce fetal expression of key endocrine transcription factors such as Pdx1 and Pax6 but simultaneously increase expression of transcription factors that regulate development of the exocrine pancreas [119].

It has also been demonstrated that the UPI or the low-protein IUPR offspring experience increased oxidative stress and impaired mitochondrial function [96, 120]. The mitochondrial dysfunction was not limited to just the beta cell, as mitochondria from both the liver and skeletal muscle exhibit decreased oxidation of pyruvate, subsequently leading to the development of features commonly found in T2D [100, 121]. Also exposure to a Western-style diet before and during pregnancy (an IUEO model) alters the redox state as early as preimplantation development, leading to mild oxidative stress associated with inflammation. The finding that administration of antioxidants to the dam reverses oxidative stress and completely prevents the development of glucose intolerance and increased adiposity in the adult offspring suggests that oxidative stress plays an important role in the development of adiposity in this case [122]. Some studies in the low-protein IUPR model have demonstrated that oxidative stress is not limited to just mitochondrial DNA damage, but also to genomic DNA, impacting cell-cycle regulation and gene expression [123]. While DNA is being targeted throughout by ROS, there are particular regions that are known to be more sensitive to ROS-mediated damage, for example, telomeres. Telomeres comprise GC-rich repeats and are found at the ends of each chromosome. They are known to shorten with each cellular division and, hence, can act as a mitotic clock, registering the number of replicative divisions to have taken place within the cell. Investigations using an IUPR model have indeed reported a decrease in longevity in the offspring $[123,124]$ accompanied by reduction in mitochondrial antioxidant defences $[96,125]$ and telomere length in islets [125].

Pancreatic islet development has been shown to be influenced by a number of growth factors including the insulinlike growth factors, IGF-I and IGF-II whose expression in utero is regulated by nutrient and hormone concentrations. IUPR modifies expression of both IGF genes in a variety of fetal tissues. In an IUPR rat model with a decreased beta-cell mass and beta-cell replication and an increased rate of beta-cell apoptosis, gene expression for IGF-II but not IGF-I was found reduced in the fetal pancreas [126]. In a different IUPR model with more severe global food restriction which induced hyperinsulinemia and an increase in beta-cell mass in their fetuses [90], the fetal phenotype was unexpectedly associated with an increase in pancreatic IGF-I expression, islet IGF-1R [91], and IRS-2 [92]. In the fetal GK/Par rat exposed to mild hyperglycemia during gestation (a model of IUED), data from our group suggest that the beta-cell deficit (reduced by more than 50\%) starts as early as fetal age E16 and reflects decreased beta-cell proliferation, a limitation of beta-cell neogenesis from precursors, and increased apoptosis of both beta cells and their precursors [86]. Notably, Pdx1 and Neurogenin3 expression were decreased on E18 but normally expressed on E13 [86]. Defective signalling through the Igf2/Igf1-R pathway may represent the primary instrumental anomaly since Igf2 and Igf1-R protein expressions are already decreased within the GK/Par pancreatic rudiment at E13, at a time when beta-cell mass (first wave of beta-cell expansion) is in fact normal [31]. Low levels of pancreatic Igf2 associated with beta-cell mass deficiency are maintained thereafter within the fetal pancreas [87]. Crossbreeding protocols between nondiabetic $\mathrm{W}$ and diabetic GK rats showed that, in late gestation (E18), pancreatic Igf2 protein expression was as low in GKmother/GKfather and Wmother/GKfather crosses as in GKmother/GKfather crosses [87]. These findings rather support the hypothesis that the pancreatic Igf 2 anomaly in the GK diabetic model is linked to a genetic determinism. This view is also consistent with the results of genetic analyses that linked a locus containing the gene encoding Igf2 to diabetes in the GK rat [127]. The Igf2 gene is subjected to paternal genomic imprinting. However, because the Igf2 expression is similarly affected in fetuses, regardless of whether the father is W or GK [87], we cannot conclude with a simple change of Igf 2 gene imprinting in the GK rat.

Finally, our understanding of the underlying mechanisms for reduced BCM in response to inappropriate perinatal nutrition is growing rapidly. However, the relative contribution of the many intrinsic and extrinsic factors which contribute to the adaptive response of the developing endocrine pancreas is still to be established.

\section{Various Early-Life Stressors: One Ultimate Programming Inducer-Perinatal Hyperglycemia}

As abundantly illustrated in animal models, early-life stressors such as maternal undernutrition, overnutrition, hypercholesterolemia, corticosteroid therapy, uteroplacental insufficiency, or hypoxia program metabolic adaptations that initially favour survival but are ultimately detrimental to adult health. Interestingly, there exists in fact one crucial commonality between these models with quite different etiologies: in most of the cases, the altered maternal/fetal metabolism appears to be associated with a diabetogenic effect in the adult offspring either male or female, resulting in a permanent deficiency of the endocrine pancreatic function (F1). In females, the combination of a latent diabetogenic tendency (low insulin response) and the metabolic stress of pregnancy promotes gestational diabetes. F1 gestational diabetes per se is an inducing factor for impaired glucose tolerance and gestational diabetes again in the next female generation (F2).

Finally, the relevant message is that programming of the endocrine pancreas ultimately originates from hyperglycemia experienced during the fetal and/or early postnatal life, whatever the etiology of maternal hyperglycemia, 
primary (in F0 diabetic mothers) or secondary (in F1 diabetic mothers issued from F0 mothers exposed to undernutrition, UPI, or high glucocorticoid) (Figure 2).

\section{Transgenerational Inheritance of Beta-Cell Mass Programming}

While a large number of animal studies have shown the effects of undernutrition during foetal/perinatal development on the glucose metabolism of offspring (F1) in adulthood, several studies have shown that glucose metabolism is also altered in the offspring (F2) as well as grand offspring (F3) of fetally malnourished F1 females, even when the F1 and F2 females have been well nourished since weaning [32, 128] (Figure 1, Table 1). With an aim to dissect the relative parental contributions that lead to F2 offspring outcomes in these models of maternal (F0) undernutrition, it was recently reported that F1 males exhibit moderate hyperglycemia and IGT with aging and impaired glucose-stimulated insulin secretion and that all F2 offspring of F1 males or F1 females develop glucose intolerance [99]. Therefore, intergenerational progression of glucose intolerance can derive from both the maternal and paternal lines. This is an experimental proof that transgenerational transmission of IGT may also occur through the paternal lineage, beside the more widely accepted maternal and grandmaternal inheritance of diabetes $[94,99,128,129]$.

Conceptually, transgenerational inheritance of disease risk may be mediated by nongenomic mechanisms, including either (1) epigenetic mechanisms [130-133] or (2) other broader indirect mechanisms associated with parental physiology [134]. First, alterations in nutrition during development can alter epigenetic marks, thus regulating gene expression through DNA methylation and/or histone modifications. Interestingly, such epigenetic modifications may progress with aging during postnatal life, in association with metabolic phenotypes, as recently observed at the Pdx1 and GLUT4 loci in UPI rats $[109,135]$. If these epigenetic changes occur in the germ line, they can be inherited through meiosis [136], thus providing a plausible explanation for intergenerational effects, transmitted via either maternal or paternal lines. In addition, other indirect biological processes may influence phenotypes in subsequent generations. For example, physical constraints may alter birth size through the maternal lineage: since uterine size is reduced in girls that are born small and remain short, this may influence fetal growth and reduce weight in their progeny [134].

Furthermore, maternal metabolism may also influence cross-generational phenotypes [32]. Maternal undernutrition during pregnancy (F0) increases risk for developing diabetes and obesity in her offspring (F1). When these high-risk adult F1 females become pregnant, the metabolic stress of pregnancy may result in hyperglycemia and/or overt gestational diabetes that may, in turn, contribute to defective beta-cell mass and increased diabetes risk in F2 offspring [32]. By this mechanism gestational diabetes may pass from one generation to the next one. In these last examples, intergenerational transmission of phenotypes would occur exclusively through the maternal lineage, as opposed to the epigenetic mechanisms mentioned above. Such a scenario is relevant to the GK/Par rat (Figure 3), since the GK/Par mothers are mildly hyperglycemic through their gestation and during the suckling period. It offers a rationale to elucidate several clues: (1) the initiation of pancreas programming in the F1 offspring of the first founders (F0), since the GK line is issued from intercrosses between Wistar females and males with borderline IGT but otherwise normal basal blood glucose level [23]; (2) the progression of the IGT phenotype until a stable mild diabetic phenotype was reached among the generations $n=30$ [23]; (3) the lack of attenuation of the diabetic GK phenotype overtime (along more than 20 years and 80 generations), since offspring of GK female/W male crosses were more hyperglycemic than those of $\mathrm{W}$ female/GK male crosses [89].

\section{Epigenetic Mechanisms Mediating the Diabetes Risk Associated with Beta-Cell Mass Programming}

Several lines of evidence indicate that epigenetic modification may be a key unifying mechanism mediating risk associated with a perturbed intrauterine environment. First, disruption of physiologic responses and functional capacity as observed in multiple tissues of IUED or IUGR animals and humans, including muscle, adipose, pancreas, liver, and CNS may be related to histone modification and DNA methylation, thereby altering related gene expression [133].

The preimplantation embryo is particularly sensitive to epigenetic modifications that might permanently alter the phenotype in the adult $[105,137]$. For example, in the agouti mouse model, folate supplementation of the maternal diet at conception increases DNA methylation of the agouti gene and increases longevity of the offspring [138]. Maternal protein restriction has been shown to alter the methylation status of the promoters of the glucocorticoid receptor [97], $\operatorname{PPAR} \alpha$ [98], and the angiotensin receptor [139] with parallel changes in gene expression. More recent studies have shown that histone modifications can also be influenced by the early environment. Alterations in histone modifications have also been implicated in mediating the effect of caloric restriction during the second half of pregnancy on the programmed reduction of GLUT4 expression in the offspring [135]. In the case of the UPI rat model and the pancreatic tissue, Stoffers and colleagues have reported a progressive reduction in expression of Pdx1, a key transcription factor regulating pancreatic development and function [69]. Pdx1 expression is reduced by $50 \%$ in UPI fetuses and by $80 \%$ in adult UPI offspring. Notably, these changes precede the onset of betacell dysfunction, suggesting a primary pathogenic role. Since the $\mathrm{Pdx} 1$ promoter is a target for epigenetic modification, as it contains a conserved $\mathrm{CpG}$ islands and is associated with high levels of histone acetylation. Interestingly, binding of both acetylated histone $\mathrm{H} 3 / \mathrm{H} 4$ and the transcription factor USF1 was found abolished in UPI fetuses [109]. While there 

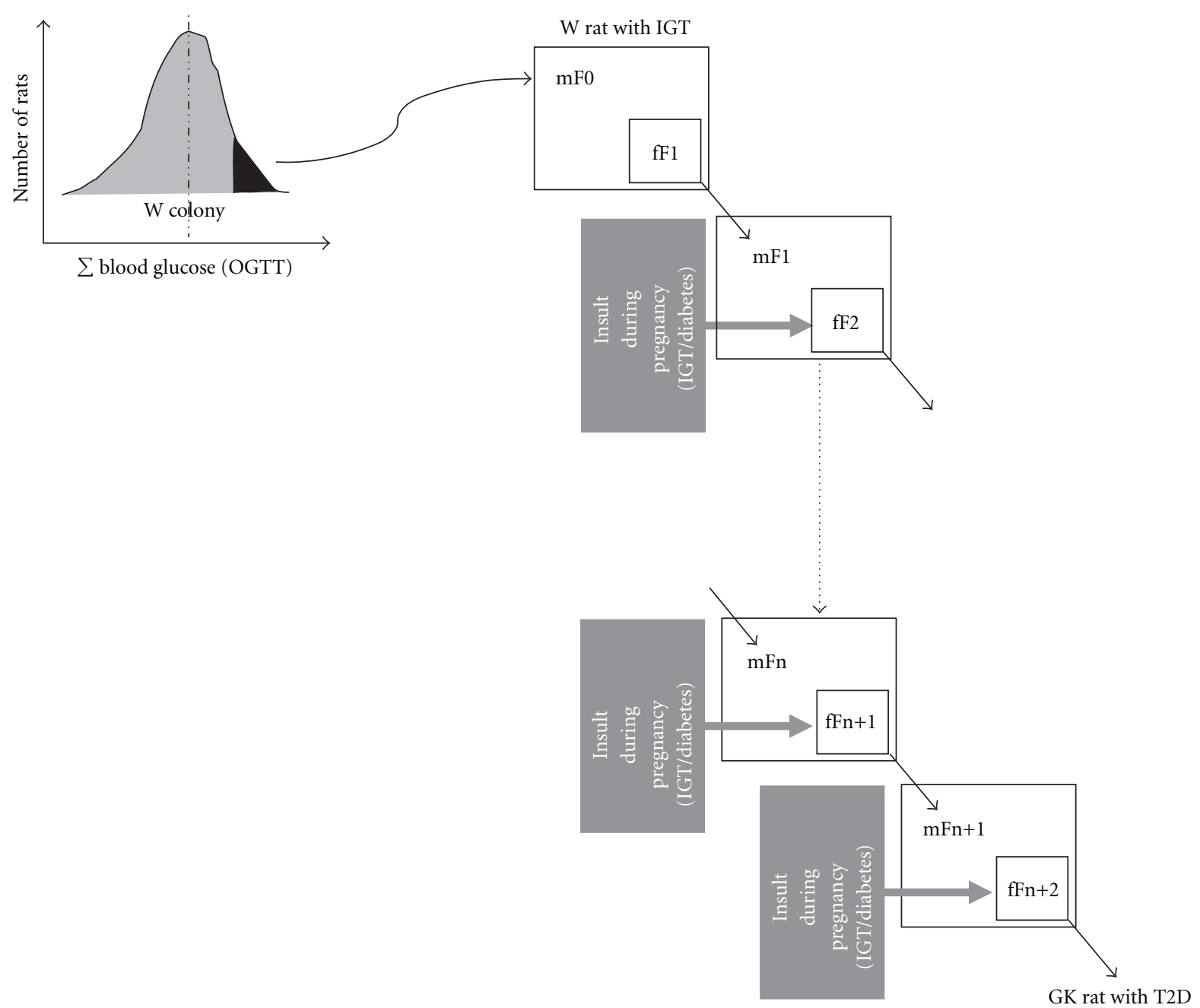

FIGURE 3: Mechanisms for the installation and intergenerational transmission of programmed beta-cell mass (BCM) disruption in the GK/Par rat model of type 2 diabetes. Maternal IGT/diabetes during gestation induces BCM programming in the first (F1) and the subsequent rat generations. Metabolic modifications in the pups during the in utero and suckling periods are followed by the onset of pathological conditions in adulthood (glucose intolerance and type 2 diabetes) and the transmission of programmed endocrine/metabolic capacities to the next generation. W: Wistar strain.

was methylation at multiple CpGs in UPI adult offspring, no methylation was detected in UPI neonates, indicating that methylation was unlikely to explain Pdx1 repression early in life. Together, these data indicate that progressive silencing of gene expression is largely initiated by early epigenetic changes and is maintained thereafter even in the absence of further experimental insults during postnatal life. UPI also increases histone acetylation of the PPAR $\gamma$ coactivator PGC1 and carnitine-palmitoyltransferase I (CPT1) promoters in newborn and young rats, and these changes are associated with increased PGC-1 and CPT1 mRNAs [101]. Finally, there is now little doubt that epigenetic regulation of gene expression also occurs in humans as a response to early nutritional insult: a recent study has revealed that individuals who were exposed to famine in utero during the Dutch Hunger Winter had altered methylation of the Igf2 gene in white blood cells in adulthood [140].

\section{Implications for Public Health}

Although the focus of most studies in the metabolic programming field has been on delineating the effects of reduced maternal nutrition, there is now a growing interest in the role of maternal overnutrition in the programming of diabetes risk. The worldwide prevalence of obesity continues to increase, in association with an increase in the risk of metabolic T2D. Indeed, a recent study estimated that the number of people worldwide with diabetes would increase from 171 million in 2000 to 366 million by 2030 if the prevalence of obesity remained constant [141], which has major implications for public health strategies worldwide [142]. This global trend to increasing obesity is reflected in the increasing numbers of women who are obese during pregnancy [143]. Given that the offspring of obese mothers have an increased risk of developing obesity and T2D 
themselves $[144,145]$, the potential impact of the intergenerational consequences of maternal obesity is of great concern for public health policy makers.

Moreover, maternal hyperglycemia per se increases the probability of adolescent obesity and future T2D. To what extent maternal hyperglycemia is fuelling the global rise in obesity and T2D is unknown, but its contribution is highly significant. The exact degree of hyperglycemia that has this effect and the exact timing in pregnancy that hyperglycemia is impressionable on fetal programming is unknown. The need to identify and treat all women with gestational diabetes is very much dependent on us knowing this. Meanwhile, achieving rigorous glycemic control in women with diabetic pregnancy has to remain a major therapeutic goal.

Several interventions (dietary or pharmacological) to reduce the long-term sequelae of early-life programming effects have been used in animal models. For example, the administration of folic acid with a low-protein diet during pregnancy prevents the altered phenotype and epigenotype in rat offspring [97], and administration of a diet rich in methyl donors prevents the transgenerational increase in obesity in agouti yellow mice [146]. Importantly, the timing of such interventions can be crucial. Examples include neonatal leptin treatment which reverses the programming effects of prenatal undernutrition [147]. In the UPI rat model, epigenetic silencing of the Pdx1 gene can be reversed during a critical developmental window in the neonatal period, using trichostatin A which inhibit HDACs [109]. In the same model, exposure to exendin-4 in the neonatal period reversed the detrimental fetal programming of the beta-cell mass and prevented the development of diabetes in adulthood: this was closely related to restoration of $\mathrm{pdx} 1$ expression and beta-cell proliferation rate [69]. A GLP-1 or exendin- 4 treatment limited to the neonatal prediabetic period was also shown to delay the installation and limit the severity of T2D in the GK/Par model [88]. In such context, it is important to note that GLP1-derived drugs that are currently used to treat patients with T2D may target chromatin remodelling. Treating beta cells from the INS1 cell line or dispersed mouse islet cells with GLP-1 increased global acetylation of histone $\mathrm{H} 3$ and increased its phosphorylation in a concentration-dependent manner [148]. Such histone modifications increased association with the transcription factor phospho-CREB and with cAMP-response CREB coactivator 2. Taken as a whole, these data may provoke optimism-that there may be a window for potential postnatal therapeutic interventions to prevent/modify the "programmed" diabetes risk.

\section{Abbreviations}

m: Mother

f: Fetus

F1: First-generation animals procreated by

parent (F0) females submitted to

experimentally disturbed metabolism during

their pregnancy
F2: $\quad$ Second-generation animals procreated by F1 females exposed to intrauterine-disturbed metabolism

IUED: In utero exposed to maternal diabetes

IUCR: In utero exposed to maternal calorie restriction

IUPR: In utero exposed to maternal protein restriction

UPI: Uteroplacental insufficiency

IUEO: In utero exposed to maternal overnutrition or obesity

BCM: Beta-cell mass.

\section{Acknowledgments}

The studies from our laboratory and referred to in this paper have been funded by the French ANR (programme Physio 2006-Prograbeta-ref. ANR-06-PHYSIO028), EGIDE (PHC franco-espagnol PICASSO 2008-2009), and NEB Association. A. Chavey received a CNRS postdoctoral fellowship and was granted by NESTLE-France and Alfediam/SFD.

\section{References}

[1] M. I. Harris, R. Klein, T. A. Welborn, and M. W. Knuiman, "Onset of NIDDM occurs at least 4-7 yr before clinical diagnosis," Diabetes Care, vol. 15, no. 7, pp. 815-819, 1992.

[2] R. A. Defronzo, "From the triumvirate to the ominous octet: a new paradigm for the treatment of type 2 diabetes mellitus," Diabetes, vol. 58, no. 4, pp. 773-795, 2009.

[3] A. E. Butler, J. Janson, S. Bonner-Weir, R. Ritzel, R. A. Rizza, and P. C. Butler, " $\beta$-cell deficit and increased $\beta$-cell apoptosis in humans with type 2 diabetes," Diabetes, vol. 52, no. 1, pp. 102-110, 2003.

[4] J. C. Florez, "Newly identified loci highlight $\beta$-cell dysfunction as a key cause of type 2 diabetes: where are the insulin resistance genes?" Diabetologia, vol. 51, no. 7, pp. 1100-1110, 2008.

[5] P. Saenger, P. Czernichow, I. Hughes, and E. O. Reiter, "Small for gestational age: short stature and beyond," Endocrine Reviews, vol. 28, no. 2, pp. 219-251, 2007.

[6] A. O. Martin, J. L. Simpson, C. Ober, and N. Freinkel, "Frequency of diabetes mellitus in mothers of probands with gestational diabetes: possible maternal influence on the predisposition to gestational diabetes," American Journal of Obstetrics and Gynecology, vol. 151, no. 4, pp. 471-475, 1985.

[7] J. C. Alcolado, K. Laji, and R. Gill-Randall, "Maternal transmission of diabetes," Diabetic Medicine, vol. 19, no. 2, pp. 89-98, 2002.

[8] D. Dabelea, R. L. Hanson, R. S. Lindsay et al., "Intrauterine exposure to diabetes conveys risks for type 2 diabetes and obesity: a study of discordant sibships," Diabetes, vol. 49, no. 12, pp. 2208-2211, 2000.

[9] E. Sobngwi, P. Boudou, F. Mauvais-Jarvis et al., "Effect of a diabetic environment in utero on predisposition to type 2 diabetes," The Lancet, vol. 361, no. 9372, pp. 1861-1865, 2003.

[10] J. F. Gautier, C. Wilson, C. Weyer et al., "Low acute insulin secretory responses in adult offspring of people with early 
onset type 2 diabetes," Diabetes, vol. 50, no. 8, pp. 1828-1833, 2001.

[11] R. L. Hanson, R. C. Elston, D. J. Pettitt, P. H. Bennett, and W. C. Knowler, "Segregation analysis of non-insulin-dependent diabetes mellitus in Pima Indians: evidence for a major-gene effect," American Journal of Human Genetics, vol. 57, no. 1, pp. 160-170, 1995.

[12] R. Singh, E. Pearson, P. J. Avery et al., "Reduced $\beta$-cell function in offspring of mothers with young-onset type 2 diabetes," Diabetologia, vol. 49, no. 8, pp. 1876-1880, 2006.

[13] D. J. Barker, C. N. Hales, C. H. Fall, C. Osmond, K. Phipps, and P. M. Clark, "Type 2 (non-insulin-dependent) diabetes mellitus, hypertension and hyperlipidaemia (syndrome X): relation to reduced fetal growth," Diabetologia, vol. 36, no. 1, pp. 62-67, 1993.

[14] D. J. P. Barker, "The developmental origins of adult disease," Journal of the American College of Nutrition, vol. 23, supplement 6, pp. 588S-595S, 2004.

[15] C. N. Hales, D. J. Barker, P. M. Clark et al., "Fetal and infant growth and impaired glucose tolerance at age 64," British Medical Journal, vol. 303, no. 6809, pp. 1019-1022, 1991.

[16] P. H. Whincup, S. J. Kaye, C. G. Owen et al., "Birth weight and risk of type 2 diabetes: a systematic review," Journal of the American Medical Association, vol. 300, no. 24, pp. 28862897, 2008.

[17] R. H. Jones and S. E. Ozanne, "Intra-uterine origins of type 2 diabetes," Archives of Physiology and Biochemistry, vol. 113, no. 1, pp. 25-29, 2007.

[18] D. I. Phillips, D. J. Barker, C. N. Hales, S. Hirst, and C. Osmond, "Thinness at birth and insulin resistance in adult life," Diabetologia, vol. 37, no. 2, pp. 150-154, 1994.

[19] J. Rahier, J. Wallon, and J. C. Henquin, "Cell populations in the endocrine pancreas of human neonates and infants," Diabetologia, vol. 20, no. 5, pp. 540-546, 1981.

[20] D. L. Economides, K. H. Nicolaides, W. A. Gahl, I. Bernardini, and M. I. Evans, "Plasma insulin in appropriate and small for gestational age fetuses," American Journal of Obstetrics and Gynecology, vol. 160, no. 5 I, pp. 1091-1094, 1989.

[21] C. Brufani, A. Grossi, D. Fintini et al., "Obese children with low birth weight demonstrate impaired $\beta$-cell function during oral glucose tolerance test," Journal of Clinical Endocrinology and Metabolism, vol. 94, no. 11, pp. 44484452, 2009.

[22] F. A. van Assche, F. de Prins, L. Aerts, and M. Verjans, "The endocrine pancreas in small-for-dates infants," British Journal of Obstetrics and Gynaecology, vol. 84, no. 10, pp. 751753, 1977.

[23] Y. Goto, M. Kakizaki, and N. Masaki, "Spontaneous diabetes produced by selective breeding of normal Wistar rats," Proceedings of the Japan Academy, vol. 51, pp. 80-85, 1975.

[24] L. Aerts, K. Holemans, and F. A. van Assche, "Maternal diabetes during pregnancy: consequences for the offspring," Diabetes/Metabolism Reviews, vol. 16, no. 3, pp. 147-197, 1990.

[25] B. Reusens-Billen, C. Remacle, J. Daniline, and J. J. Hoet, "Cell proliferation in pancreatic islets of rat fetuses and neonates from normal and diabetic mothers. An in vitro and in vivo study," Hormone and Metabolic Research, vol. 16, no. 11, pp. 565-571, 1984.

[26] B. Reusens and C. Remacle, "Intergenerational effect of an adverse intrauterine environment on perturbation of glucose metabolism," Twin Research, vol. 4, no. 5, pp. 406-411, 2001.
[27] A. Kervran, M. Guillaume, and A. Jost, "The endocrine pancreas of the fetus from diabetic pregnant rat," Diabetologia, vol. 15, no. 5, pp. 387-393, 1978.

[28] L. Aerts, L. Vercruysse, and F. A. van Assche, "The endocrine pancreas in virgin and pregnant offspring of diabetic pregnant rats," Diabetes Research and Clinical Practice, vol. 38, no. 1, pp. 9-19, 1997.

[29] J. Verhaeghe, T. L. Peeters, M. Vandeputte, W. Rombauts, R. Bouillon, and F. A. van Assche, "Maternal and fetal endocrine pancreas in the spontaneously diabetic BB rat," Biology of the Neonate, vol. 55, no. 4-5, pp. 298-308, 1989.

[30] P. Serradas, M. N. Gangnerau, M. H. Giroix, C. Saulnier, and B. Portha, "Impaired pancreatic $\beta$-cell function in the fetal GK rat. Impact of diabetic inheritance," Journal of Clinical Investigation, vol. 101, no. 4, pp. 899-904, 1998.

[31] F. Miralles and B. Portha, "Early development of $\beta$-cells is impaired in the GK rat model of type 2 diabetes," Diabetes, vol. 50, supplement 1, pp. S84-S88, 2001.

[32] L. Aerts and F. A. van Assche, "Animal evidence for the transgenerational development of diabetes mellitus," International Journal of Biochemistry and Cell Biology, vol. 38, no. 5-6, pp. 894-903, 2006.

[33] J. Han, J. Xu, Y. S. Long, P. N. Epstein, and Y. Q. Liu, "Rat maternal diabetes impairs pancreatic $\beta$-cell function in the offspring," American Journal of Physiology-Endocrinology and Metabolism, vol. 293, no. 1, pp. E228-E236, 2007.

[34] V. Grill, B. Johansson, P. Jalkanen, and U. J. Eriksson, "Influence of severe diabetes mellitus early in pregnancy in the rat: effects on insulin sensitivity and insulin secretion in the offspring," Diabetologia, vol. 34, no. 6, pp. 373-378, 1991.

[35] A. Ktorza, D. Gauguier, M. T. Bihoreau, M. F. Berthault, and L. Picon, "Adult offspring from mildly hyperglycemic rats show impairment of glucose regulation and insulin secretion which is transmissible to the next generation," in Frontiers in Diabetic Research. Lessons from Animal Diabetes, E. Shafrir, Ed., pp. 555-560, Smith-Gordon and Company, London, UK, 1990.

[36] W. Oh, N. L. Gelardi, and C. J. Cha, "Maternal hyperglycemia in pregnant rats: its effect on growth and carbohydrate metabolism in the offspring," Metabolism, vol. 37, no. 12, pp. 1146-1151, 1988.

[37] D. Gauguier, M. T. Bihoreau, L. Picon, and A. Ktorza, "Insulin secretion in adult rats after intrauterine exposure to mild hyperglycemia during late gestation," Diabetes, vol. 40, supplement 2, pp. 109-114, 1991.

[38] M. T. Bihoreau, A. Ktorza, M. F. Kinebanyan, and L. Picon, "Impaired glucose homeostasis in adult rats from hyperglycemic mothers," Diabetes, vol. 35, no. 9, pp. 979984, 1986.

[39] E. A. Ryan, D. Liu, R. C. Bell, D. T. Finegood, and J. Crawford, "Long term consequences in offspring of diabetes in pregnancy: studies with syngeneic islet-transplanted streptozotocin-diabetic rats," Endocrinology, vol. 136, no. 12, pp. 5587-5592, 1995.

[40] N. Triadou, B. Portha, L. Picon, and G. Rosselin, "Experimental chemical diabetes and pregnancy in the rat. Evolution of glucose tolerance and insulin response," Diabetes, vol. 31, no. 1, pp. 75-79, 1982.

[41] R. Gill-Randall, D. Adams, R. L. Ollerton, M. Lewis, and J. C. Alcolado, "Type 2 diabetes mellitus-genes or intrauterine environment? An embryo transfer paradigm in rats," Diabetologia, vol. 47, no. 8, pp. 1354-1359, 2004.

[42] A. Chavey, M. N. Gangnerau, L. Maulny et al., "Intrauterine programming of $\beta$-cell development and function by 
maternal diabetes. What does embryo-transfer experiments in GK/Par rats tell us?" Diabetologia, vol. 51, supplement 1, p. $151 \mathrm{~A}, 2008$.

[43] B. Portha, A. Chavey, L. Maulny et al., "Des modèles animaux pour étudier l'origine développementale des maladies métaboliques de l'adulte: application à l'étude du risque de diabète," Cahiers de Nutrition et de Diététique, vol. 44, no. 2, pp. 77-84, 2009.

[44] A. Garofano, P. Czernichow, and B. Bréant, "In utero undernutrition impairs rat $\beta$-cell development," Diabetologia, vol. 40, no. 10, pp. 1231-1234, 1997.

[45] E. Bertin, M. N. Gangnerau, G. Bellon, D. Bailbe, A. A. de Vacqueur, and B. Portha, "Development of $\beta$-cell mass in fetuses of rats deprived of protein and/or energy in last trimester of pregnancy," American Journal of PhysiologyRegulatory Integrative and Comparative Physiology, vol. 283, no. 3, pp. R623-R630, 2002.

[46] M. A. Martín, C. Alvarez, L. Goya, B. Portha, and A. M. Pascual-Leone, "Insulin secretion in adult rats that had experienced different underfeeding patterns during their development," American Journal of Physiology, vol. 272, no. 4, pp. E634-E640, 1997.

[47] A. Garofano, P. Czernichow, and B. Bréant, " $\beta$-cell mass and proliferation following late fetal and early postnatal malnutrition in the rat," Diabetologia, vol. 41, no. 9, pp. 1114-1120, 1998.

[48] A. Garofano, P. Czernichow, and B. Bréant, "Effect of ageing on $\beta$-cell mass and function in rats malnourished during the perinatal period," Diabetologia, vol. 42, no. 6, pp. 711-718, 1999.

[49] B. Portha, M. Kergoat, O. Blondel, and D. Bailbé, "Underfeeding of rat mothers during the first two trimesters of gestation does not alter insulin action and insulin secretion in the progeny," European Journal of Endocrinology, vol. 133, no. 4, pp. 475-482, 1995.

[50] A. Snoeck, C. Remacle, B. Reusens, and J. J. Hoet, "Effect of a low protein diet during pregnancy on the fetal rat endocrine pancreas," Biology of the Neonate, vol. 57, no. 2, pp. 107-118, 1990.

[51] S. Dahri, A. Snoeck, B. Reusens-Billen, C. Remacle, and J. J. Hoet, "Islet function in offspring of mothers on low-protein diet during gestation," Diabetes, vol. 40, no. 2, pp. 115-120, 1991.

[52] S. C. Langley-Evans and M. Nwagwu, "Impaired growth and increased glucocorticoid-sensitive enzyme activities in tissues of rat fetuses exposed to maternal low protein diets," Life Sciences, vol. 63, no. 7, pp. 605-615, 1998.

[53] M. Desai, N. J. Crowther, A. Lucas, and C. N. Hales, "Organ-selective growth in the offspring of protein-restricted mothers," British Journal of Nutrition, vol. 76, no. 4, pp. 591603, 1996.

[54] D. S. Fernandez-Twinn, A. Wayman, S. Ekizoglou, M. S. Martin, C. N. Hales, and S. E. Ozanne, "Maternal protein restriction leads to hyperinsulinaemia and reduced insulinsignaling protein expression in 21-mo-old female rat offspring," American journal of physiology Regulatory integrative and comparative physiology, vol. 288, no. 2, pp. R368-R373, 2005.

[55] D. S. Fernandez-Twinn, S. E. Ozanne, S. Ekizoglou et al., "The maternal endocrine environment in the low-protein model of intra-uterine restriction," British Journal of Nutrition, vol. 90, no. 4, pp. 815-822, 2003.

[56] S. E. Ozanne, C. L. Wang, C. J. Petry, J. M. Smith, and C. N. Hales, "Ketosis resistance in the male offspring of protein-malnourished rat dams," Metabolism: Clinical and Experimental, vol. 47, no. 12, pp. 1450-1454, 1998.

[57] P. R. Shepherd, N. J. Crowther, M. Desai, C. N. Hales, and S. E. Ozanne, "Altered adipocyte properties in the offspring of protein malnourished rats," British Journal of Nutrition, vol. 78, no. 1, pp. 121-129, 1997.

[58] C. J. Petry, M. W. Dorling, D. B. Pawlak, S. E. Ozanne, and C. N. Hales, "Diabetes in old male offspring of rat dams fed a reduced protein diet," International Journal of Experimental Diabetes Research, vol. 2, no. 2, pp. 139-143, 2001.

[59] S. E. Ozanne, M. W. Dorling, C. L. Wang, and C. J. Petry, "Depot-specific effects of early growth retardation on adipocyte insulin action," Hormone and Metabolic Research, vol. 32, no. 2, pp. 71-75, 2000.

[60] S. E. Ozanne, G. D. Smith, J. Tikerpae, and C. N. Hales, "Altered regulation of hepatic glucose output in the male offspring of protein-malnourished rat dams," American Journal of Physiology, vol. 270, no. 4, pp. E559-E564, 1996.

[61] S. E. Ozanne, C. B. Jensen, K. J. Tingey, H. Storgaard, S. Madsbad, and A. A. Vaag, "Low birthweight is associated with specific changes in muscle insulin-signalling protein expression," Diabetologia, vol. 48, no. 3, pp. 547-552, 2005.

[62] S. C. Langley-Evans, A. J. Langley-Evans, and M. C. Marchand, "Nutritional programming of blood pressure and renal morphology," Archives of Physiology and Biochemistry, vol. 111, no. 1, pp. 8-16, 2003.

[63] E. S. Ogata, M. Bussey, and S. Finley, "Altered gas exchange, limited glucose and branched chain amino acids, and hypoinsulinism retard fetal growth in the rat," Metabolism, vol. 35, no. 10, pp. 970-977, 1986.

[64] R. A. Simmons, A. S. Gounis, S. A. Bangalore, and E. S. Ogata, "Intrauterine growth retardation: fetal glucose transport is diminished in lung but spared in brain," Pediatric Research, vol. 31, no. 1, pp. 59-63, 1992.

[65] T. Unterman, R. Lascon, M. B. Gotway et al., "Circulating levels of insulin-like growth factor binding protein-1 (IGFBP-1) and hepatic mRNA are increased in the small for gestational age (SGA) fetal rat," Endocrinology, vol. 127, no. 4, pp. 20352037, 1990.

[66] R. A. Simmons, L. J. Templeton, and S. J. Gertz, "Intrauterine growth retardation leads to the development of type 2 diabetes in the rat," Diabetes, vol. 50, no. 10, pp. 2279-2286, 2001.

[67] J. Boloker, S. J. Gertz, and R. A. Simmons, "Gestational diabetes leads to the development of diabetes in adulthood in the rat," Diabetes, vol. 51, no. 5, pp. 1499-1506, 2002.

[68] K. Holemans, L. Aerts, and F. A. van Assche, "Lifetime consequences of abnormal fetal pancreatic development," Journal of Physiology, vol. 547, no. 1, pp. 11-20, 2003.

[69] D. A. Stoffers, B. M. Desai, D. D. DeLeon, and R. A. Simmons, "Neonatal exendin-4 prevents the development of diabetes in the intrauterine growth retarded rat," Diabetes, vol. 52, no. 3, pp. 734-740, 2003.

[70] M. Srinivasan, S. D. Karewa, A. Palaniyappan, J. D. Pandya, and M. S. Patel, "Maternal high-fat diet consumption results in fetal programming predisposing to the onset of metabolic syndrome-like phenotype in adulthood," American Journal of Physiology_Endocrinology and Metabolism, vol. 291, no. 4, pp. E792-E799, 2006.

[71] F. Guo and K. L. Jen, "High-fat feeding during pregnancy and lactation affects offspring metabolism in rats," Physiology and Behavior, vol. 57, no. 4, pp. 681-686, 1995.

[72] P. D. Taylor, J. McConnell, I. Y. Khan et al., "Impaired glucose homeostasis and mitochondrial abnormalities in offspring of 
rats fed a fat-rich diet in pregnancy," American Journal of Physiology-Regulatory Integrative and Comparative Physiology, vol. 288, no. 1, pp. R134-R139, 2005.

[73] S. Dyrskog, S. Gregersen, and K. Hermansen, "High-fat feeding during gestation ans nursing period have diffrentail effects on the insulin secretory capacity in offspring from normal wistar rats," Review of Diabetic Studies, vol. 2, no. 3, pp. 136-145, 2005.

[74] P. Nivoit, C. Morens, F. A. van Assche et al., "Established dietinduced obesity in female rats leads to offspring hyperphagia, adiposity and insulin resistance," Diabetologia, vol. 52, no. 6, pp. 1133-1142, 2009.

[75] I. Y. Khan, V. Dekou, G. Douglas et al., "A high-fat diet during rat pregnancy or suckling induces cardiovascular dysfunction in adult offspring," American Journal of PhysiologyRegulatory Integrative and Comparative Physiology, vol. 288, no. 1, pp. R127-R133, 2005.

[76] I. Y. Khan, P. D. Taylor, V. Dekou et al., "Gender-linked hypertension in offspring of lard-fed pregnant rats," Hypertension, vol. 41, no. 1, pp. 168-175, 2003.

[77] S. C. Langley-Evans, "Intrauterine programming of hypertension in the rat: nutrient interactions," Comparative Biochemistry and Physiology A, vol. 114, no. 4, pp. 327-333, 1996.

[78] H. B. Karnik, B. R. Sonawane, J. S. Adkins, and S. Mohla, "High dietary fat feeding during perinatal development of rats alters hepatic drug metabolism of progeny," Developmental Pharmacology and Therapeutics, vol. 14, no. 2, pp. 135140, 1990.

[79] W. Palinski, F. P. D’Armiento, J. L. Witztum et al., "Maternal hypercholesterolemia and treatment during pregnancy influence the long-term progression of atherosclerosis in offspring of rabbits," Circulation Research, vol. 89, no. 11, pp. 991-996, 2001.

[80] M. E. Cerf, K. Williams, X. I. Nkomo et al., "Islet cell response in the neonatal rat after exposure to a high-fat diet during pregnancy," American Journal of PhysiologyRegulatory Integrative and Comparative Physiology, vol. 288, no. 5, pp. R1122-R1128, 2005.

[81] J. Han, J. Xu, P. N. Epstein, and Y. Q. Liu, "Long-term effect of maternal obesity on pancreatic $\beta$-cells of offspring: reduced beta cell adaptation to high glucose and high-fat diet challenges in adult female mouse offspring," Diabetologia, vol. 48, no. 9, pp. 1810-1818, 2005.

[82] G. A. Dunn and T. L. Bale, "Maternal high-fat diet promotes body length increases and insulin insensitivity in secondgeneration mice," Endocrinology, vol. 150, no. 11, pp. 4999 5009, 2009.

[83] S. F. Ng, R. Lin, D. R. Laybutt, R. Barres, J. A. Owens, and M. J. Morris, "Chronic high-fat diet in fathers programs $\beta 2$ cell dysfunction in female rat offspring," Nature, vol. 467, no. 7318, pp. 963-966, 2010.

[84] K. K. S. Bhasin, A. van Nas, L. J. Martin et al., "Maternal low-protein diet or hypercholesterolemia reduces circulating essential amino acids and leads to intrauterine growth restriction," Diabetes, vol. 58, no. 3, pp. 559-566, 2009.

[85] L. Aerts, R. van Bree, V. Feytons, W. Rombauts, and F. A. van Assche, "Plasma amino acids in diabetic pregnant rats and in their fetal and adult offspring," Biology of the Neonate, vol. 56, no. 1, pp. 31-39, 1989.

[86] S. Calderari, M. N. Gangnerau, M. Thibault et al., "Defective IGF-2 and IGF-1R protein production in embryonic pancreas precedes $\beta$-cell mass anomaly in the Goto-Kakizaki rat model of type 2 diabetes," Diabetologia, vol. 50, no. 7, pp. 1463-1471, 2007.
[87] P. Serradas, L. Goya, M. Lacorne et al., "Fetal insulin-like growth factor-2 production is impaired in the GK rat model of type 2 diabetes," Diabetes, vol. 51, no. 2, pp. 392-397, 2002.

[88] C. Tourrel, D. Bailbé, M. Lacorne, M. -J. Meile, M. Kergoat, and B. Portha, "Persistent improvement of type 2 diabetes in the Goto-Kakizaki rat model by expansion of the $\beta$-cell mass during the prediabetic period with glucagon-like peptide-1 or exendin-4," Diabetes, vol. 51, no. 5, pp. 1443-1452, 2002.

[89] D. Gauguier, I. Nelson, C. Bernard et al., "Higher maternal than paternal inheritance of diabetes in GK rats," Diabetes, vol. 43, no. 2, pp. 220-224, 1994.

[90] C. Alvarez, M. A. Martín, L. Goya, E. Bertin, B. Portha, and A. M. Pascual-Leone, "Contrasted impact of maternal rat food restriction on the fetal endocrine pancreas," Endocrinology, vol. 138, no. 6, pp. 2267-2273, 1997.

[91] M. A. Martin, P. Serradas, S. Ramos et al., "Protein-caloric food restriction affects insulin-like growth factor system in fetal Wistar rat," Endocrinology, vol. 146, no. 3, pp. 13641371, 2005.

[92] E. Fernandez, M. A. Martin, S. Fajardo, F. Escriva, and C. Alvarez, "Increased IRS-2 content and activation of IGF1 pathway contribute to enhance beta-cell mass in fetuses from undernourished pregnant rats," American Journal of Physiology-Regulatory Integrative and Comparative Physiology, vol. 292, no. 1, pp. E187-E195, 2007.

[93] A. V. Matveyenko, I. Singh, B. C. Shin, S. Georgia, and S. U. Devaskar, "Differential effects of prenatal and postnatal nutritional environment on $\beta$-cell mass development and turnover in male and female rats," Endocrinology, vol. 151, no. 12, pp. 5647-5656, 2010.

[94] B. Blondeau, I. Avril, B. Duchene, and B. Bréant, "Endocrine pancreas development is altered in foetuses from rats previously showing intra-uterine growth retardation in response to malnutrition," Diabetologia, vol. 45 , no. 3, pp. 394-401, 2002.

[95] O. Dumortier, B. Blondeau, B. Duvillié, B. Reusens, B. Bréant, and C. Remacle, "Different mechanisms operating during different critical time-windows reduce rat fetal $\beta$ cell mass due to a maternal low-protein or low-energy diet," Diabetologia, vol. 50, no. 12, pp. 2495-2503, 2007.

[96] N. Theys, T. Bouckenooghe, M. T. Ahn, C. Remacle, and B. Reusens, "Maternal low-protein diet alters pancreatic islet mitochondrial function in a sex-specific manner in the adult rat," American Journal of Physiology-Regulatory Integrative and Comparative Physiology, vol. 297, no. 5, pp. R1516R1525, 2009.

[97] K. A. Lillycrop, E. S. Phillips, A. A. Jackson, M. A. Hanson, and G. C. Burdge, "Dietary protein restriction of pregnant rats induces and folic acid supplementation prevents epigenetic modification of hepatic gene expression in the offspring," Journal of Nutrition, vol. 135, no. 6, pp. 13821386, 2005.

[98] K. A. Lillycrop, E. S. Phillips, C. Torrens, M. A. Hanson, A. A. Jackson, and G. C. Burdge, "Feeding pregnant rats a proteinrestricted diet persistently alters the methylation of specific cytosines in the hepatic PPAR $\alpha$ promoter of the offspring," British Journal of Nutrition, vol. 100, no. 2, pp. 278-282, 2008.

[99] E. Zambrano, P. M. Martinez-Samayoa, C. J. Bautista et al., "Sex differences in transgenerational alterations of growth and metabolism in progeny $\left(\mathrm{F}_{2}\right)$ of female offspring $\left(\mathrm{F}_{1}\right)$ of rats fed a low protein diet during pregnancy and lactation," Journal of Physiology, vol. 566, no. 1, pp. 225-236, 2005.

[100] M. A. Selak, B. T. Storey, I. Peterside, and R. A. Simmons, "Impaired oxidative phosphorylation in skeletal muscle 
of intrauterine growth-retarded rats," American Journal of Physiology-Endocrinology and Metabolism, vol. 285, no. 1, pp. E130-E137, 2003.

[101] Q. Fu, R. A. McKnight, X. Yu, L. Wang, C. W. Callaway, and R. H. Lane, "Uteroplacental insufficiency induces sitespecific changes in histone $\mathrm{H} 3$ covalent modifications and affects DNA-histone H3 positioning in day 0 IUGR rat liver," Physiological Genomics, vol. 20, pp. 108-116, 2005.

[102] W. Y. Kwong, A. E. Wild, P. Roberts, A. C. Willis, and T. P. Fleming, "Maternal undernutrition during the preimplantation period of rat development causes blastocyst abnormalities and programming of postnatal hypertension," Development, vol. 127, no. 19, pp. 4195-4202, 2000.

[103] R. G. Lea, J. E. McCracken, S. S. McIntyre, W. Smith, and J. D. Baird, "Disturbed development of the preimplantation embryo in the insulin-dependent diabetic BB/E rat," Diabetes, vol. 45, no. 11, pp. 1463-1470, 1996.

[104] S. Pampfer, I. Vanderheyden, J. E. McCracken, J. Vesela, and R. de Hertogh, "Increased cell death in rat blastocysts exposed to maternal diabetes in utero and to high glucose or tumor necrosis factor- $\alpha$ in vitro," Development, vol. 124, no. 23, pp. 4827-4836, 1997.

[105] W. Reik, I. Römer, S. C. Barton, M. A. Surani, S. K. Howlett, and J. Klose, "Adult phenotype in the mouse can be affected by epigenetic in the early embryo," Development, vol. 119, no. 3, pp. 933-942, 1993.

[106] W. Dean, L. Bowden, A. Aitchison et al., "Altered imprinted gene methylation and expression in completely ES cellderived mouse fetuses: association with aberrant phenotypes," Development, vol. 125, no. 12, pp. 2273-2282, 1998.

[107] M. S. Patel and M. Srinivasan, "Metabolic programming: causes and consequences," Journal of Biological Chemistry, vol. 277, no. 3, pp. 1629-1632, 2002.

[108] B. Z. Stanger, A. J. Tanaka, and D. A. Melton, "Organ size is limited by the number of embryonic progenitor cells in the pancreas but not the liver," Nature, vol. 445, no. 7130, pp. 886-891, 2007.

[109] J. H. Park, D. A. Stoffers, R. D. Nicholls, and R. A. Simmons, "Development of type 2 diabetes following intrauterine growth retardation in rats is associated with progressive epigenetic silencing of Pdx1," Journal of Clinical Investigation, vol. 118, no. 6, pp. 2316-2324, 2008.

[110] R. N. Kulkarni, U. S. Jhala, J. N. Winnay, S. Krajewski, M. Montminy, and C. R. Kahn, "PDX-1 haploinsufficiency limits the compensatory islet hyperplasia that occurs in response to insulin resistance," Journal of Clinical Investigation, vol. 114, no. 6, pp. 828-836, 2004.

[111] S. K. Chakrabarti, J. Francis, S. M. Ziesmann, J. C. Garmey, and R. G. Mirmira, "Covalent histone modifications underlie the developmental regulation of insulin gene transcription in pancreatic $\beta$ cells," Journal of Biological Chemistry, vol. 278, no. 26, pp. 23617-23623, 2003.

[112] J. Francis, S. K. Chakrabarti, J. C. Garmey, and R. G. Mirmira, "PDX-1 links histone H3-Lys-4 methylation to RNA polymerase II elongation during activation of insulin transcription," Journal of Biological Chemistry, vol. 280, no. 43, pp. 36244-36253, 2005.

[113] T. G. Deering, T. Ogihara, A. P. Trace, B. Maier, and R. G. Mirmira, "Methyltransferase set7/9 maintains transcription and euchromatin structure at islet-enriched genes," Diabetes, vol. 58, no. 1, pp. 185-193, 2009.

[114] A. L. Siebel, A. Z. Fernandez, and A. El-Osta, "Glycemic memory associated epigenetic changes," Biochemical Pharmacology, vol. 80, no. 12, pp. 1853-1859, 2010.
[115] J. R. Seckl, "Prenatal glucocorticoids and long-term programming," European Journal of Endocrinology, vol. 151, spplement 3, pp. U49-U62, 2004.

[116] B. Blondeau, J. Lesage, P. Czernichow, J. P. Dupouy, and B. Bréant, "Glucocorticoids impair fetal $\beta$-cell development in rats," American Journal of Physiology-Regulatory Integrative and Comparative Physiology, vol. 281, no. 3, pp. E592-E599, 2001.

[117] B. Bréant, E. Gesina, and B. Blondeau, "Nutrition, glucocorticoids and pancreas development," Hormone Research, vol. 65, supplement 3, pp. 98-104, 2006.

[118] A. de Vries, M. C. Holmes, A. Heijnis et al., "Prenatal dexamethasone exposure induces changes in nonhuman primate offspring cardiometabolic and hypothalamic-pituitaryadrenal axis function," Journal of Clinical Investigation, vol. 117, no. 4, pp. 1058-1067, 2007.

[119] E. Gesina, F. Tronche, P. Herrera et al., "Dissecting the role of glucocorticoids on pancreas development," Diabetes, vol. 53, no. 9, pp. 2322-2329, 2004.

[120] R. A. Simmons, I. Suponitsky-Kroyter, and M. A. Selak, "Progressive accumulation of mitochondrial DNA mutations and decline in mitochondrial function lead to $\beta$-cell failure," Journal of Biological Chemistry, vol. 280, no. 31, pp. 2878528791, 2005.

[121] I. E. Peterside, M. A. Selak, and R. A. Simmons, "Impaired oxidative phosphorylation in hepatic mitochondria in growth-retarded rats," American Journal of PhysiologyEndocrinology and Metabolism, vol. 285, no. 6, pp. E1258E1266, 2003.

[122] S. Sen and R. A. Simmons, "Maternal antioxidant supplementation prevents adiposity in the offspring of western dietfed rats," Diabetes, vol. 59, no. 12, pp. 3058-3065, 2010.

[123] J. H. Chen, C. N. Hales, and S. E. Ozanne, "DNA damage, cellular senescence and organismal ageing: causal or correlative?" Nucleic Acids Research, vol. 35, no. 22, pp. 7417-7428, 2007.

[124] B. J. Jennings, S. E. Ozanne, M. W. Dorling, and C. N. Hales, "Early growth determines longevity in male rats and may be related to telomere shortening in the kidney," FEBS Letters, vol. 448, no. 1, pp. 4-8, 1999.

[125] J. L. Tarry-Adkins, J. H. Chen, N. S. Smith, R. H. Jones, H. Cherif, and S. E. Ozanne, "Poor maternal nutrition followed by accelerated postnatal growth leads to telomere shortening and increased markers of cell senescence in rat islets," FASEB Journal, vol. 23, no. 5, pp. 1521-1528, 2009.

[126] J. Petrik, B. Reusens, E. Arany et al., "A low protein diet alters the balance of islet cell replication and apoptosis in the fetal and neonatal rat and is associated with a reduced pancreatic expression of insulin-like growth factor-II," Endocrinology, vol. 140, no. 10, pp. 4861-4873, 1999.

[127] D. Gauguier, P. Froguel, V. Parent et al., "Chromosomal mapping of genetic loci associated with non-insulin dependent diabetes in the GK rat," Nature Genetics, vol. 12, no. 1, pp. 38-43, 1996.

[128] D. C. Benyshek, C. S. Johnston, and J. F. Martin, "Glucose metabolism is altered in the adequately-nourished grandoffspring (F3 generation) of rats malnourished during gestation and perinatal life," Diabetologia, vol. 49, no. 5, pp. 1117-1119, 2006.

[129] A. J. Drake, B. R. Walker, and J. R. Seckl, "Intergenerational consequences of fetal programming by in utero exposure to glucocorticoids in rats," American Journal of PhysiologyRegulatory Integrative and Comparative Physiology, vol. 288, no. 1, pp. R34-R38, 2005. 
[130] S. E. Ozanne and M. Constancia, "Mechanisms of disease: the developmental origins of disease and the role of the epigenotype," Nature Clinical Practice Endocrinology and Metabolism, vol. 3, no. 7, pp. 539-546, 2007.

[131] S. E. Pinney and R. A. Simmons, "Epigenetic mechanisms in the development of type 2 diabetes," Trends in Endocrinology and Metabolism, vol. 21, no. 4, pp. 223-229, 2009.

[132] A. J. Drake and L. Liu, "Intergenerational transmission of programmed effects: public health consequences," Trends in Endocrinology and Metabolism, vol. 21, no. 4, pp. 206-213, 2010.

[133] R. A. Waterland and K. B. Michels, "Epigenetic epidemiology of the developmental origins hypothesis," Annual Review of Nutrition, vol. 27, pp. 363-388, 2007.

[134] P. D. Gluckman, M. A. Hanson, and A. S. Beedle, "Nongenomic transgenerational inheritance of disease risk," BioEssays, vol. 29, no. 2, pp. 145-154, 2007.

[135] N. Raychaudhuri, S. Raychaudhuri, M. Thamotharan, and S. U. Devaskar, "Histone code modifications repress glucose transporter 4 expression in the intrauterine growth-restricted offspring," Journal of Biological Chemistry, vol. 283, no. 20, pp. 13611-13626, 2008.

[136] S. Chong, N. Vickaryous, A. Ashe et al., "Modifiers of epigenetic reprogramming show paternal effects in the mouse," Nature Genetics, vol. 39, no. 5, pp. 614-622, 2007.

[137] A. S. Doherty, M. R. Mann, K. D. Tremblay, M. S. Bartolomei, and R. M. Schultz, "Differential effects of culture on imprinted $\mathrm{H} 19$ expression in the preimplantation mouse embryo," Biology of Reproduction, vol. 62, no. 6, pp. 1526$1535,2000$.

[138] C. A. Cooney, A. A. Dave, and G. L. Wolff, "Maternal methyl supplements in mice affect epigenetic variation and DNA methylation of offspring," Journal of Nutrition, vol. 132, no. 8, pp. 2393S-2400S, 2002.

[139] I. Bogdarina, S. Welham, P. J. King, S. P. Burns, and A. J. Clark, "Epigenetic modification of the renin-angiotensin system in the fetal programming of hypertension," Circulation Research, vol. 100, no. 4, pp. 520-526, 2007.

[140] B. T. Heijmans, E. W. Tobi, A. D. Stein et al., "Persistent epigenetic differences associated with prenatal exposure to famine in humans," Proceedings of the National Academy of Sciences of the United States of America, vol. 105, no. 44, pp. 17046-17049, 2008.

[141] S. Wild, G. Roglic, A. Green, R. Sicree, and H. King, "Global prevalence of diabetes: estimates for the year 2000 and projections for 2030," Diabetes Care, vol. 27, no. 5, pp. 10471053, 2004.

[142] World Health Organisation, "Obesity: preventing and managing the global epidemic. Report of a WHO consultation," WHO Technical Report Series, World Health Organisation, Geneva, Switzerland, 2000.

[143] M. G. Kanagalingam, N. G. Forouhi, I. A. Greer, and N. Sattar, "Changes in booking body mass index over a decade: retrospective analysis from a Glasgow maternity hospital," British Journal of Obstetrics and Gynaecology, vol. 112, no. 10, pp. 1431-1433, 2005.

[144] P. M. Catalano, "Obesity and pregnancy-the propagation of a viscous cycle?" Journal of Clinical Endocrinology and Metabolism, vol. 88, no. 8, pp. 3505-3506, 2003.

[145] P. M. Catalano, K. Farrell, A. Thomas et al., "Perinatal risk factors for childhood obesity and metabolic dysregulation," American Journal of Clinical Nutrition, vol. 90, no. 5, pp. 1303-1313, 2009.
[146] R. A. Waterland, M. Travisano, K. G. Tahiliani, M. T. Rached, and S. Mirza, "Methyl donor supplementation prevents transgenerational amplification of obesity," International Journal of Obesity, vol. 32, no. 9, pp. 1373-1379, 2008.

[147] M. H. Vickers, P. D. Gluckman, A. H. Coveny et al., "Neonatal leptin treatment reverses developmental programming," Endocrinology, vol. 146, no. 10, pp. 4211-4216, 2005.

[148] S. J. Kim, C. Nian, and C. H. S. McIntosh, "Glucosedependent insulinotropic polypeptide and glucagon-like peptide-1 modulate $\beta$-cell chromatin structure," Journal of Biological Chemistry, vol. 284, no. 19, pp. 12896-12904, 2009. 


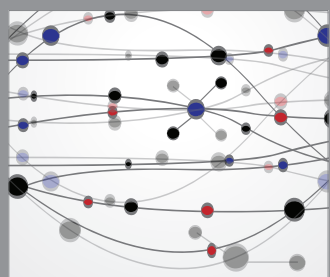

The Scientific World Journal
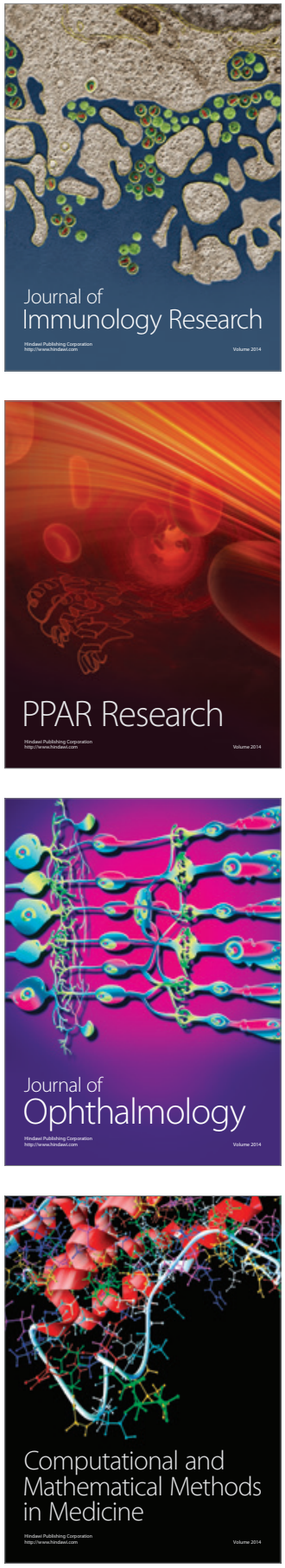

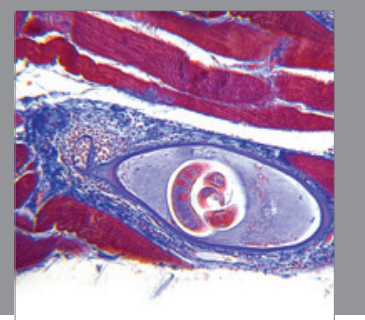

Gastroenterology

Research and Practice
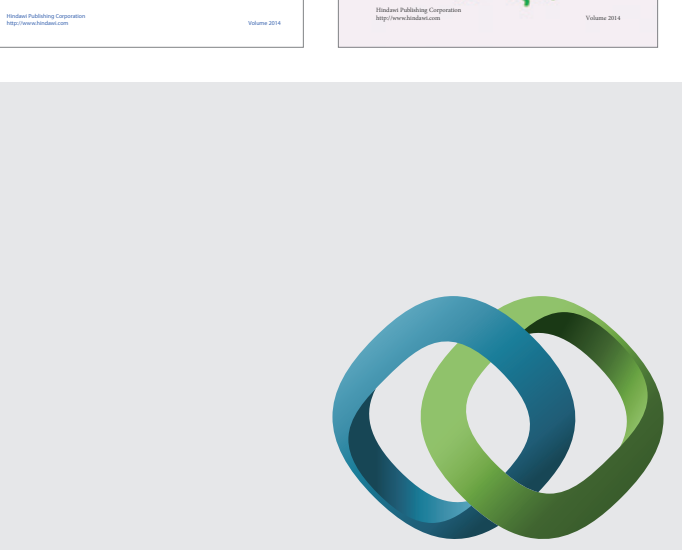

\section{Hindawi}

Submit your manuscripts at

http://www.hindawi.com
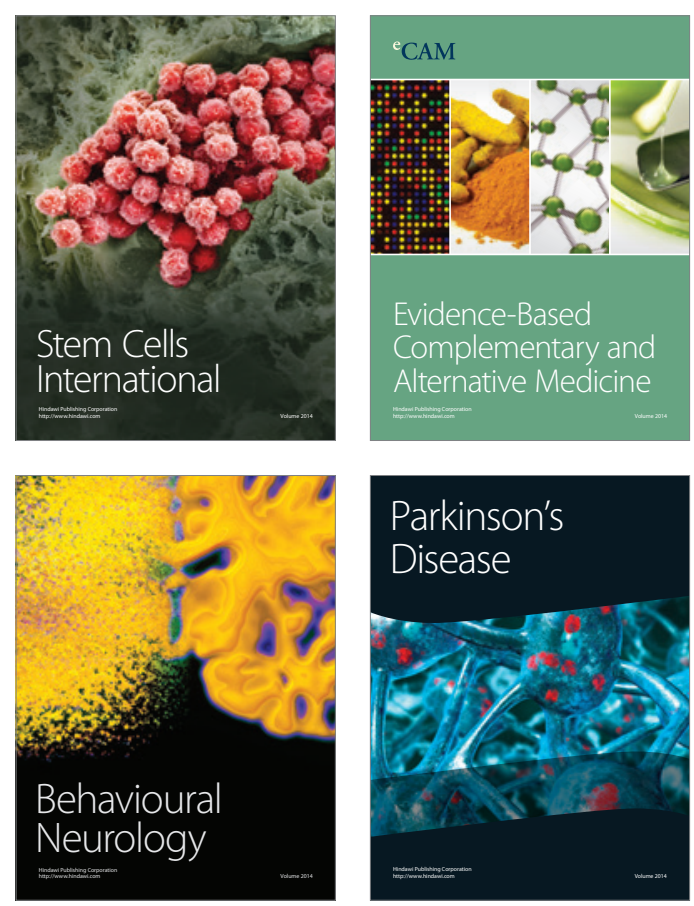

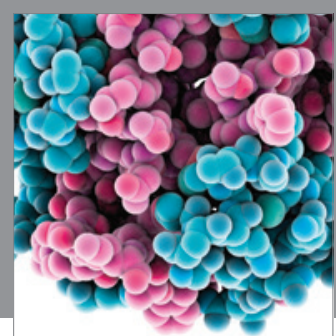

Journal of
Diabetes Research

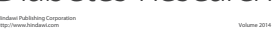

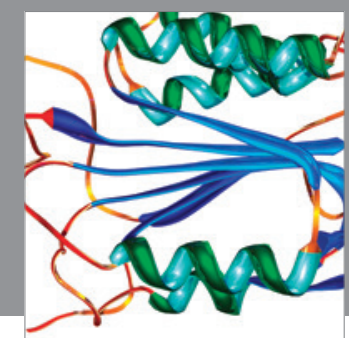

Disease Markers
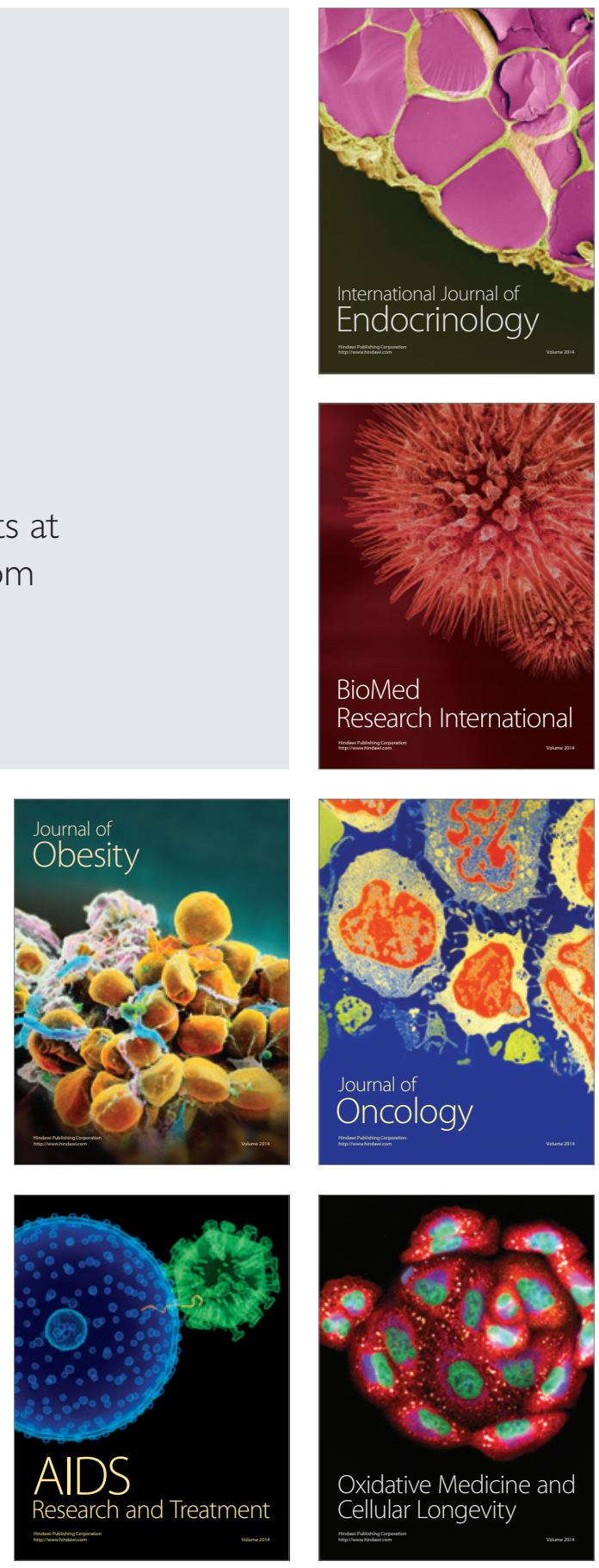